\title{
From nucleotides to ribozymes - A comparison of their metal ion binding properties
}

\author{
Freisinger, Eva ; Sigel, Roland K O
}

\begin{abstract}
It is undisputable that the fates of metal ions and nucleic acids are inescapably interwoven. Metal ions are essential for charge compensation of the negatively charged phosphate-sugar backbone, they are instrumental for proper folding, and last but not least they are crucial cofactors for ribozyme catalysis. Considerable progress has been achieved in the past few years on the identification of metal ion binding sites in large DNA and RNA molecules, like in ribozymes including the ribosome. Hereby, most information was gained from crystallography, which fails to explain metal ion binding equilibria in solution as well as the factors that determine the coordination of a metal ion to a specific site. In contrast, such information is readily available for the low-molecular building blocks of large nucleic acids, i.e. for mononucleotides and to some extent also dinucleotides. In this review, we combine and compare for the first time both sets of information. The focus is thereby set on $\mathrm{Mg} 2+, \mathrm{Ca} 2+, \mathrm{Mn} 2+$, and $\mathrm{Cd} 2+$ because these four metal ions are either freely available in cells, have a large impact on the catalytic rate of ribozymes, and/or are often applied in RNA biochemistry. Our comparisons show that results obtained from small molecules can be directly transposed to the findings in large RNA structures like the ribosome. For example, the basic coordination-chemical properties of the different metal ions are reflected in their binding to large nucleic acid structures: macrochelate formation, e.g. the simultaneous intranucleotide coordination of a $\mathrm{Mg} 2+$ ion to the phosphate unit and the N7 site of a purine nucleobase (be it inner- or outersphere), is well known for mononucleotides. We show that the frequency of occurrence of this type of coordination is the same for mononucleotides and the ribosome.
\end{abstract}

DOI: https://doi.org/10.1016/j.ccr.2007.03.008

Posted at the Zurich Open Repository and Archive, University of Zurich

ZORA URL: https://doi.org/10.5167/uzh-59908

Journal Article

Accepted Version

Originally published at:

Freisinger, Eva; Sigel, Roland K O (2007). From nucleotides to ribozymes - A comparison of their metal ion binding properties. Coordination Chemistry Reviews, 251(13-14):1834-1851.

DOI: https://doi.org/10.1016/j.ccr.2007.03.008 


\title{
From nucleotides to ribozymes - a comparison of their metal ion binding properties
}

\author{
Eva Freisinger, Roland K. O. Sigel* \\ Institute of Inorganic Chemistry, University of Zürich, Winterthurerstrasse 190, \\ CH-8057 Zürich, Switzerland
}

Received:

Accepted:

* Corresponding author: Tel.: +41-44-635 4652; fax: +41-44-635 6802.

E-mail address: roland.sigel@aci.unizh.ch (R. K. O. Sigel). 


\section{Contents}

Abstract

1. Introduction

2. Control of reaction rates by metal ions in DNAzymes and ribozymes

3. Metal ion binding to the building blocks of RNA and DNA

3.1. Metal ion binding to mononucleotides

3.1.1. Comments on the structure and function of nucleotides in solution

3.1.2. Stability of metal ion-nucleotide complexes in solution

3.1.3. Insights from crystallography

3.2. Metal ion binding to dinucleotides

3.3. The effect of structural preorientation in dinucleotides on metal ion binding

4. Metal ion binding to ribozymes and DNA

4.1. $\mathrm{Mg}^{2+}$ binding to the ribosome

4.2. Metal ion binding to the HIV dimerization initiation site

4.3. Metal ion binding to the Dickerson-Drew DNA dodecamer

5. Conclusions and outlook

Abbreviations and definitions

Acknowledgements

References 


\section{Abstract}

It is undisputable that the fates of metal ions and nucleic acids are inescapably interwoven. Metal ions are essential for charge compensation of the negatively charged phosphate-sugar backbone, they are instrumental for proper folding, and last but not least they are crucial cofactors for ribozyme catalysis. Considerable progress has been achieved in the past few years on the identification of metal ion binding sites in large DNA and RNA molecules, like in ribozymes including the ribosome. Hereby, most information was gained from crystallography, which consequently often fails to explain metal ion-binding equilibria in solution as well as the factors that determine the coordination of a metal ion to a specific site. In contrast, such information is readily available for the low-molecular building blocks of large nucleic acids, i.e. for mono- and to some extent also dinucleotides. In this review, we combine and compare for the first time both sets of information. The focus is thereby set on $\mathrm{Mg}^{2+}, \mathrm{Ca}^{2+}, \mathrm{Mn}^{2+}$, and $\mathrm{Cd}^{2+}$ because these four metal ions are either freely available in cells, have a large impact on the catalytic rate of ribozymes, and/or are often applied in RNA biochemistry. Our comparisons show that results obtained from small molecules can be directly transposed to the findings in large RNA structures like the ribosome. For example, the basic coordination-chemical properties of the different metal ions are reflected in their binding to large nucleic acid structures: Macrochelate formation, e.g. the simultaneous coordination of a $\mathrm{Mg}^{2+}$ ion to a phosphate unit and the N7 site of a purine nucleobase, is well known for mononucleotides. We show that the frequency of occurrence of this type of coordination is the same for mononucleotides and the ribosome.

Keywords: Nucleic acids; mono- and dinucleotides; metal ions; RNA/DNA; ribozymes 


\section{Introduction}

Any RNA or nucleic acid is a polyanion due to the negatively charged phosphate-sugar backbone. Nevertheless, large RNAs fold to very complex three-dimensional structures containing not only A-form helices but also loops, bulges, and many other local structures, which form a multitude of tertiary contacts [1-4]. Consequently, negative charges accumulate in close space and need to be neutralized site-specifically in order to enable such close packing of the backbones. This is only achievable by positive charges of high density, i.e. metal ions [5-8]. The major task of charge compensation along the backbone is certainly taken over by monovalent ions $\left(\mathrm{Na}^{+}, \mathrm{K}^{+}\right)$[9], loosely bound divalent metal ions [10-14], and to some extent also by polycharged organic cations like spermine [7,15-18]. However, it is evident that divalent metal ions are the major source of specifically and locally bound positive charges within nucleic acids or living cells in general [7,8,19-22].

Among the divalent metal ions, $\mathrm{Mg}^{2+}$ is certainly the most abundant one being freely available in any cell and thus thought to be involved majorily with RNA folding and catalysis [7,8,23-26]. Unfortunately, in terms of experimental detectability, $\mathrm{Mg}^{2+}$ is a nuisance because it offers no direct spectroscopic handle for detection, and its equal number of electrons makes it difficult to distinguish from $\mathrm{H}_{2} \mathrm{O}$ or $\mathrm{Na}^{+}$in crystal structures [27]: High resolution is needed to identify $\mathrm{Mg}^{2+}$ ions in large nucleic acid structures, but most often such high resolution is not reached. In addition, to make the situation more complicated, one is interested only in a handful of $\mathrm{Mg}^{2+}$ ions bound at specific sites - but these are located within a vast sea of more loosely bound ions of the same kind around the RNA [21]. Among the specific sites only very few offer such a high affinity that they are saturated before others are filled up $[7,21,28]$, e.g. triphosphate groups [29-32], positions within a pseudoknot [33,34], or a tetraloop-tetraloop receptor motif [35]. One possibility to monitor and investigate simultaneously metal ion binding to different sites including the characterization of the individual binding affinities is offered by $\mathrm{Mg}^{2+}$ titration experiments using NMR spectroscopy [29-31,36]. However, in most 
cases, as a consequence of the above mentioned limitations, experimental strategies are followed by employing other metal ions than $\mathrm{Mg}^{2+}$. To name just a few examples, (i) heavy atom derivatives for phasing in X-ray crystallography, (ii) lanthanide(III) ions [20,21,28], $\mathrm{Pb}^{2+}$ or transition metal ions $[37,38]$ in hydrolytic cleavage experiments, (iii) lanthanide(III) ions in activity assays to elucidate the mechanism of ribozyme reactions [28], (iv) paramagnetic metal ions for EPR $[39,40]$, and (v) the application of $\mathrm{d}^{10}$ or transition metal ions in NMR spectroscopy [29,41-43]. Many of such experiments have provided very valuable information on the location and role of distinct metal ions. However, the results are always associated with the caveat that another metal ion than the (presumably) native $\mathrm{Mg}^{2+}$ has been used - and it is evident from uncountable articles that every ion has its distinctive coordination chemistry.

As mentioned above, $\mathrm{Mg}^{2+}$ is certainly the divalent metal ion to be involved majorily with RNA. However, it is dangerous to neglect all other metal ions with respect to RNA in natural systems, simply because they are not freely available in large quantities in every cell: It is well known that most metalloproteins function on the basis of (redox active) metal ions that are highly toxic if freely available. These enzymes are thus chaperoned and loaded specifically with such ions [44]. Why should a similar mechanism not exist for RNA? In fact, there is growing evidence that other metal ions than $\mathrm{Mg}^{2+}$ can accelerate ribozyme reactions by manifolds, e.g. in the case of the hammerhead ribozyme [45-47]. In addition, there are several examples of both naturally occurring and in vitro designed ribozymes and DNAzymes [8,48-52], which show a fast decrease in reaction kinetics if trace amounts of other metal ions are present aside from the inherent one. It is therefore evident that not only $\mathrm{Mg}^{2+}$ but other metal ions as well need to be considered in order to understand the structure and functioning of nucleic acids in general, and of ribozymes specifically.

Summarizing the above paragraphs, a huge amount of information on $\mathrm{M}^{\mathrm{n}+}$ binding to RNAs and their role in several catalytic mechanisms could be gained over the past years ... 
with the already mentioned reservations: No other metal ion behaves absolutely identical to $\mathrm{Mg}^{2+}$ in terms of binding strength, coordination preferences, or simply size. It is therefore well feasible that incorrect conclusions regarding $\mathrm{Mg}^{2+}$ have been drawn and misleading paths were followed when results obtained for $\mathrm{Mg}^{2+}$-mimicking metal ions where prematurely assigned to $\mathrm{Mg}^{2+}$ itself. In order to interpret and validate the richness of data gained from such mimicking experiments and/or to discover and understand alternative metabolic pathways including nucleic acids and metal ions, more and better information needs to be collected. Ideally an accurate knowledge of the distinct binding properties and preferences of each metal ion towards RNA or nucleic acids in general is highly desirable.

Such accurate data is scarce for larger nucleic acids, but small molecules like nucleobases, nucleosides, nucleotides or dinucleotides have been examined rigorously over the past years. Thereby, a wealth of very accurate binding data for the most common metal ions to the building blocks of nucleic acids has accumulated. In this review, we combine for the first time the wealth of information existing on the binding properties of $\mathrm{Mg}^{2+}, \mathrm{Ca}^{2+}$, $\mathrm{Mn}^{2+}$, and $\mathrm{Cd}^{2+}$ to mononucleotides and to dinucleotides in order to compare this information directly with what is known about the complexing properties of larger RNA and DNA structures (a summary of some physico-chemical properties of these four metal ions is given in Table 1). We have selected these four metal ions because (i) $\mathrm{Mg}^{2+}$ is the divalent metal ion freely available in every cell, (ii) $\mathrm{Ca}^{2+}$ is a neurotransmitter and is also present in millimolar concentrations within certain cell compartments (although highly regulated) [53-58], (iii) $\mathrm{Mn}^{2+}$ is known to accelerate the catalytic rate of some ribozymes [45-47] and is often used as a probe in EPR [39,40] and NMR studies [59], and (iv) $\mathrm{Cd}^{2+}$ is also often considered a good mimic of $\mathrm{Mg}^{2+}$ and is thus commonly used in thio-rescue studies [60,61].

In the following sections, first a few examples on the effects of the mentioned metal ions on the reactivity of some ribozymes are summarized in order to illustrate some possibilities how metal ions might be used to regulate the reactivity of nucleic acids in vivo. In the next 
part, the binding properties of $\mathrm{Mg}^{2+}, \mathrm{Ca}^{2+}, \mathrm{Mn}^{2+}$, and $\mathrm{Cd}^{2+}$ to the building blocks of nucleic acids are shortly reviewed and thereafter this data is compared to the results obtained from large RNA structures.

It is the aim of this review to draw parallels between the coordination chemistry of large nucleic acids and their building blocks, as well as to highlight the crucial differences in the coordinating properties of the four mentioned metal ions towards large DNAs as well as ribozymes and their building blocks. This will not only facilitate the interpretation of results from the field of RNA biochemistry, but it will also help to design experiments and sometimes even to predict the binding of metal ions to certain sites and their influence on the structure and activity of ribozymes.

\section{Control of reaction rates by metal ions in DNAzymes and ribozymes}

Several examples are known of naturally occurring ribozymes as well as of in vitro selected ribozymes and especially DNAzymes, which are either highly selective for a given kind of metal ion, where the assumption may be raised that $\mathrm{Mg}^{2+}$ is not the natural cofactor, or where the activity might be controlled by switching the kind of metal ion involved [8,45-52].

The hammerhead ribozyme was one of the first catalytic RNAs to be discovered and has been the focus of uncountable studies on its structure and the function of metal ions in catalysis. This data has been excellently reviewed [7,28,62-66] and therefore only the most important points regarding metal ion coordination will be mention here. The hammerhead ribozyme is active in the presence of millimolar amounts of $\mathrm{Mg}^{2+}$, however, it retains its activity when $\mathrm{Mg}^{2+}$ is replaced by high molar amounts of monovalent cations like $\mathrm{Li}^{+}, \mathrm{Na}^{+}$ and also $\mathrm{NH}_{4}^{+}$[67-69]. As in addition, many experiments have indicated that binding of divalent metal ions only occurs 10-20 $\AA$ away from the cleavage site [69-72], these results have been repeatedly taken as evidence that metal ions are not directly involved in the catalytic step. However, these findings could also be interpreted as an indication that the role 
of these metal ions is more of an electrostatic nature, e.g. by stabilizing the transition state of the phosphodiester cleavage [7]. Even more interesting in the present context is the fact that the so-called minimal hammerhead ribozyme (which represents the best characterized hammerhead sequence) does not show its best activity in the presence of $\mathrm{Mg}^{2+}$ but $\mathrm{Mn}^{2+}[73]$. This observation is even more pronounced in the case of the recently described so-called extended hammerhead ribozyme [69,74-76], where so far the maximum cleavage rate has not been reached $[45,46,74]$. Interestingly, aside from $\mathrm{Mn}^{2+}$ also other transition metal ions like $\mathrm{Co}^{2+}$ or $\mathrm{Ni}^{2+}$, as well as $\mathrm{Zn}^{2+}$ and $\mathrm{Cd}^{2+}$ lead to higher cleavage rates than $\mathrm{Mg}^{2+}$ [46]. It can therefore be speculated that the hammerhead ribozyme represents an example where $\mathrm{Mg}^{2+}$ is not the natural cofactor, but instead another divalent metal ion (perhaps even a redox active one) is used for in vivo function.

Another example of naturally occurring ribozymes where divalent metal ions have been shown to strongly influence the catalytic rate are self-splicing group II intron ribozymes $[8,48,52]$. Group II introns are very large catalytic RNAs and second in size only to the ribosome $[8,77]$. For every group II intron investigated today, $\mathrm{Mg}^{2+}$ has been shown to be the essential divalent metal ion that must not be omitted $[8,23,25,77,78]$ as it is required for folding $[79,80]$ and presumably also for catalysis $[60,81-83]$. In the case of the Sc.ai5 $\gamma$ group II intron from yeast, $\mathrm{Mg}^{2+}$ can be partially replaced by $\mathrm{d}^{10}$ metal ions like $\mathrm{Cd}^{2+}$ or $\mathrm{Zn}^{2+}$ (and also $\mathrm{Mn}^{2+}$ ) and retains activity, as is evident from so-called thio-rescue experiments $[60,84,85]$. However, when small amounts of $\mathrm{Mg}^{2+}$ are replaced by $\mathrm{Ca}^{2+}$, an immediate drop in splicing activity can be observed $[8,48,52]$. This is highly interesting because $\mathrm{Ca}^{2+}$ plays an important role in living cells. Although tightly regulated due to its role as a neurotransmitter, $\mathrm{Ca}^{2+}$ concentrations can reach millimolar concentrations within certain cell compartments like mitochondria, which act as $\mathrm{Ca}^{2+}$ storage vesicles [53-58]. As Sc.ai5 $\gamma$ is located within the cytochrome oxidase 1 gene of mitochondrial DNA, it is reasonable to assume that the varying levels of freely available $\mathrm{Ca}^{2+}$ in this cell compartment also influence the splicing rate in vivo 
and therefore might be used to regulate other cellular reactions.

Examples exist where the metal ion specificity of naturally occurring ribozymes can be switched by appropriate mutations within the catalytic core. One such example encompasses group I introns. Usually, these large ribozymes have a strict requirement for either $\mathrm{Mg}^{2+}$ or $\mathrm{Mn}^{2+}$ to carry out catalytic activity [47]. This specificity could be switched completely to a selective requirement for $\mathrm{Ca}^{2+}$ by in vitro selection in both the Tetrahymena $[86,87]$ as well as the Azoarcus group I intron [47]. However, it is unclear why a specificity exists in the first place and further how the few introduced single point mutations alter the metal ion specificity. Interestingly, two recent crystal structures of the Azoarcus group I intron [88,89] show that one of the two $\mathrm{Mg}^{2+}$ ions present in the catalytic core can be replaced by $\mathrm{K}^{+}$. This indicates that indeed different metal ions compete for exactly the same site, although obviously their coordinating properties are different, but it is unknown how this affects catalysis.

In vitro selection experiments offer the opportunity to select nucleic acids with a high specificity for a certain kind of metal ion. One example is provided by variants of the socalled 8-17 DNAzymes [90-93], which are active in the presence of $\mathrm{Mg}^{2+}, \mathrm{Ca}^{2+}$, and $\mathrm{Zn}^{2+}$. The cleavage rate under similar conditions thereby decreases in the order $\mathrm{Zn}^{2+}>>\mathrm{Ca}^{2+}>$ $\mathrm{Mg}^{2+}[90,94,95]$. Ironically, the variant $17 \mathrm{E}$ shows its highest activity in the presence of $\mathrm{Pb}^{2+}$ - a metal ion it was not selected for $[49,96]$. This DNAzyme has lately been further developed and is now used as a highly selective luminescent sensor for $\mathrm{Pb}^{2+}$ ions [96-100]. However, despite the intense research on this and related DNAzymes, to date no structural data is available that allows a conclusion regarding the coordination-chemical basis on which the different cleavage rates in the presence of different metal ions and the high selectivity for $\mathrm{Pb}^{2+}$ are founded. Obviously, a better knowledge of the coordination chemistry involved would allow to rationally design and/or improve further applications and selectivities.

To summarize, there is ample precedence in catalytic RNAs and DNAs that a high selectivity for metal ions is present and may by used to trigger and control the function of 
specific molecules. However, to the best of our knowledge no system has been described where the detailed effect of the metal ion switch is known on the atomic level. In the following section we will therefore summarize the available knowledge on the exact coordination modes of $\mathrm{Mg}^{2+}, \mathrm{Ca}^{2+}, \mathrm{Mn}^{2+}$, and $\mathrm{Cd}^{2+}$ to the low-molecular building blocks of large nucleic acids.

\section{Metal ion binding to the building blocks of RNA and DNA}

\section{1. $\quad$ Metal ion binding to mononucleotides}

\subsubsection{Comments on the structure and function of nucleotides in solution}

Mononucleotides, either in their mono-, di- or triphosphorylated form, are very abundant in living cells serving a multitude of different functions (for their structures and labeling schemes see Fig. 1). In their triphosphorylated form (i.e. (d)NTPs with "N" being any nucleobase and "d" indicating the 2'-deoxy form of the ribose moiety) they constitute the building blocks for nucleic acid polymerases in the syntheses of RNA and DNA. In addition, ATP and to some extent also GTP serve as main energy sources for many enzymatic reactions in any organism and are further employed as neurotransmitters. These and other nucleotides are also important cofactors or substrates for enzymatic reactions including those where either the nucleobase (e.g. deaminases) [101,102] or the sugar moiety (e.g. ribonucleotide reductases) [103] are modified. No matter in which function, nucleotides are always associated with metal ions due to the negatively charged phosphate residues.

However, metal ions are not only present for charge compensation, but they may also actively take part in enzymatic reactions and determine by their binding mode the path which a reaction follows [104-106]: Simultaneous $\beta-/ \gamma$-coordination of one of the two metal ions coordinated to the triphosphate chain of a (d)NTP (the second metal ion is coordinated to the $\alpha$-phosphate) leads to a cleavage of the anhydride bond between the $\alpha$ - and the $\beta$-phosphate groups (Fig. 1), as also catalyzed by nucleic acid polymerases [107-109]. In contrast, $\alpha-/ \beta$ - 
coordination of the first and $\gamma$-coordination of the second metal ion leads to the release of the terminal $\gamma$-phosphate group, as e.g. in kinases [105,110,111].

It is interesting to note in the present context that with an excess of metal ions a total of two ions will coordinate to the 5'-triphosphate chain. In the absence of further coordinating ligands, such as a protein scaffold, one metal ion is $\alpha$-/ $\beta$-bound (in equilibrium) and the other one is located at the terminal $\gamma$-phosphate group [104,105,112]. Hence, mainly hydrolysis to the nucleoside diphosphate and free monophosphate (i.e. kinase activity) will occur [104]. It is remarkable that even in such simple systems, the rate of hydrolysis is increased tremendously if a mixture of two different metal ions (e.g. $\mathrm{Mg}^{2+}$ and $\mathrm{Cu}^{2+}$ ) is used [112]. This illustrates nicely that the two coordinated metal ions serve different purposes, thus giving rise to synergism, and that even in such simple systems discrimination among metal ions occurs. One may therefore speculate if not also different kinds of metal ions coordinate to specific binding pockets within more complex systems like ribozymes leading to synergistic effects.

\subsubsection{Stability of metal ion-nucleotide complexes in solution}

Complex formation of any metal ion with a nucleotide can be described by the following equilibrium:

$$
\begin{aligned}
& \mathrm{M}^{2+}+\mathrm{NXP}^{\mathrm{y}-} \rightleftarrows \mathrm{M}(\mathrm{NXP})^{(\mathrm{y}-2)-} \\
& K_{\mathrm{M}(\mathrm{NXP})}^{\mathrm{M}}=\frac{\left[\mathrm{M}(\mathrm{NXP})^{(\mathrm{y}-2)-}\right]}{\left[\mathrm{M}^{2+}\right]\left[\mathrm{NXP}^{\mathrm{y}-}\right]}
\end{aligned}
$$

$\mathrm{NXP}^{\mathrm{y}-}$ denotes the mono-, di-, or triphosphate form of any nucleotide or 2'-deoxy nucleotide, whereby " $y$ " is the corresponding charge value $(y=2$ for the nucleoside mono-, $y=3$ for the di-, and $y=4$ for the tri-phosphate). Please note that the competition of a metal ion with the proton bound at the terminal phosphate group is not considered in this equilibrium. Such a proton is released with a $\mathrm{p} K_{\mathrm{a}}$ value of about 6.2 for nucleoside $5^{\prime}$-monophosphates, $\mathrm{H}(\mathrm{NMP})^{-}$, and $6.50 \pm 0.05$ for nucleoside 5 '-triphosphates, $\mathrm{H}(\mathrm{NTP})^{3-}[113-116]$, and has thus hardly any 
influence on the extent of metal ion coordination in the physiological $\mathrm{pH}$ range of about 7.5 (for more details see e.g. refs. $[115,117,118]$ ). Irrespective of the number of phosphate groups present at the 5'-end, this residue is always the primary binding site for alkaline, alkaline earth, and $3 \mathrm{~d}$ transition metal ions, as well as $\mathrm{Zn}^{2+}$ or $\mathrm{Cd}^{2+}$.

It is well known that with purine-nucleoside 5'-phosphates a further, namely an intramolecular equilibrium exists: The phosphate-coordinated metal ion can form a macrochelate by interacting with N7 of the nucleobase moiety. This macrochelate formation gives rise to the following intramolecular equilibrium (2):
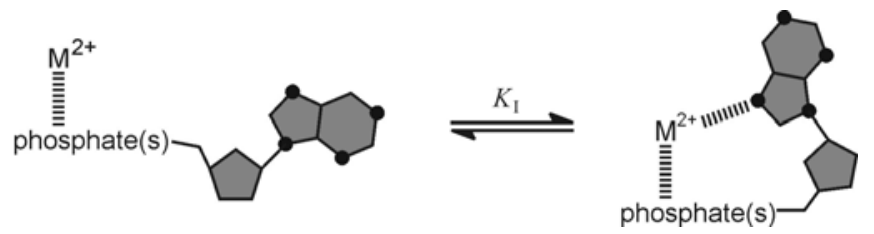

It is important to note that the formation degree of the macrochelated or "closed" species, $\mathrm{M}(\mathrm{NXP})_{\mathrm{cl}}^{(2-\mathrm{y})-}$, is independent of the total complex concentration because it is an intramolecular equilibrium. Therefore, its equilibrium constant $K_{\mathrm{I}}$, as defined by equation (3), is dimensionless $[117,119,120]$ :

$$
K_{\mathrm{I}}=\frac{\left[\mathrm{M}(\mathrm{NXP})_{\mathrm{cl}}^{(\mathrm{y}-2)-}\right]}{\left[\mathrm{M}(\mathrm{NXP})_{\mathrm{op}}^{(\mathrm{y}-2)-}\right]}
$$

$\mathrm{M}(\mathrm{NXP})_{\mathrm{op}}^{(2-y)-}$ refers to the "open", i.e. solely phosphate-coordinated, species, and hence equilibrium (1a) may be rewritten as given in (4):

$$
\mathrm{M}^{2+}+\mathrm{NXP}^{\mathrm{y}-} \stackrel{K_{\mathrm{M}(\mathrm{NXP})_{\text {op }}}^{\mathrm{M}}}{\rightleftharpoons} \mathrm{M}(\mathrm{NXP})_{\mathrm{op}}^{(\mathrm{y}-2)-} \stackrel{K_{\perp}}{\rightleftharpoons} \mathrm{M}(\mathrm{NXP})_{\mathrm{cl}}^{(\mathrm{y}-2)-}
$$

$K_{\mathrm{M}(\mathrm{NXP})_{\text {op }}}^{\mathrm{M}}$ thereby represents the stability constant of the open species. The stability increase, $\log \Delta$, due to macrochelate formation is defined by equation (5),

$$
\log \Delta=\log \Delta_{\mathrm{M}(\mathrm{NXP})}=\log K_{\mathrm{M}(\mathrm{NXP})}^{\mathrm{M}}-\log K_{\mathrm{M}(\mathrm{NXP})_{\text {op }}}^{\mathrm{M}}
$$

and the intramolecular equilibrium constant $K_{\mathrm{I}}$ can then be calculated with equation (6): 


$$
K_{\mathrm{I}}=\frac{K_{\mathrm{M}(\mathrm{NXP})}^{\mathrm{M}}}{K_{\mathrm{M}(\mathrm{NXP})_{\mathrm{op}}}^{\mathrm{M}}}-1=10^{\log \Delta}-1
$$

Based on the value of $K_{\mathrm{I}}$, the formation degree of the closed species can be calculated for any kind of nucleotide-metal ion complex by equation (7):

$$
\% \mathrm{M}(\mathrm{NXP})_{\mathrm{cl}}^{(\mathrm{y}-2)-}=100 \frac{K_{\mathrm{I}}}{1+K_{\mathrm{I}}}
$$

These $\% \mathrm{M}(\mathrm{NXP})_{\mathrm{cl}}^{(\mathrm{y}-2)-}$ values for the various metal ions discussed here, i.e. $\mathrm{Mg}^{2+}, \mathrm{Ca}^{2+}, \mathrm{Mn}^{2+}$, and $\mathrm{Cd}^{2+}$, are summarized in Tables 2 and 3 for several purine-nucleotide systems. Each value represents the tendency of the specific metal ion for macrochelate formation, or in other words, its affinity for the N7 position when already bound to the phosphate terminus (for a more detailed derivation of equations (3) - (7), please refer to refs. [119-121]).

Comparison of the data accumulated in Tables 2 and 3 reveals the following distinct differences between $\mathrm{Mg}^{2+}, \mathrm{Ca}^{2+}, \mathrm{Mn}^{2+}$, and $\mathrm{Cd}^{2+}$ in terms of their overall binding affinity in general, as well as their ability to simultaneously coordinate to the phosphate group(s) and the purine N7 position, i.e. to form a macrochelate:

(i) For each of the four metal ions discussed here, the stability constants $\log K_{\mathrm{M}(\mathrm{NXP})_{\mathrm{op}}}^{\mathrm{M}}$, representing the pure phosphate coordination of a given metal ion in a $\mathrm{M}(\mathrm{NXP})^{(\mathrm{y}-2)-}$ complex, increase in the order of $\mathrm{NMP}^{2-}<\mathrm{NDP}^{3-}<\mathrm{NTP}^{4-}$ (Fig. 2). This is certainly to be expected as an additional stabilization by chelate formation becomes possible with an increasing number of phosphate units. Furthermore, the negative charge increases by one unit with each additional phosphate group. It should be noted that the nature of the nucleobase has virtually no influence on the binding affinity of a certain metal ion to the 5'-phosphate chain alone, e.g. the $\log K_{\mathrm{M}(\mathrm{NXP})_{\mathrm{op}}}^{\mathrm{M}}$ values for $\mathrm{Mg}^{2+}$ binding to $\mathrm{AMP}^{2-}$ and $\mathrm{GMP}^{2-}$ are the same within their error limits. The very minor difference of $0.01 \log$ unit is due to a similarly small difference in phosphate basicity (e.g. $\mathrm{p} K_{\mathrm{H}(\mathrm{AMP})}^{\mathrm{H}}=6.21 \pm 0.01$ and $\left.\mathrm{p} K_{\mathrm{H}(\mathrm{GMP})}^{\mathrm{H}}=6.25 \pm 0.02\right)$ [122]. 
Consequently, also in a large nucleic acid structure, each monophosphate diester group is expected to exhibit the same affinity towards a given metal ion irrespective of its position within the primary sequence and the attached nucleobase. It follows that other factors, i.e. additional binding sites or steric restrictions, must be responsible for any discrimination observed.

(ii) For all $\mathrm{NXP}^{\mathrm{y}-}$ ligands, the stability constant $\log K_{\mathrm{M}(\mathrm{NXP})_{\mathrm{op}}}^{\mathrm{M}}$ of the $\mathrm{M}(\mathrm{NXP})_{\mathrm{op}}^{(\mathrm{y}-2)-}$ complexes increases in the order of $\mathrm{Ca}^{2+}<\mathrm{Mg}^{2+}<\mathrm{Mn}^{2+}<\mathrm{Cd}^{2+}$. The lower stability of the $\mathrm{Ca}^{2+}$ complexes compared to those of $\mathrm{Mg}^{2+}$ can thereby be explained by the larger ionic radius of $\mathrm{Ca}^{2+}(72 \mathrm{pm}$ versus $100 \mathrm{pm}$ for coordination number $\mathrm{CN}=6)$. The affinities of $\mathrm{Mn}^{2+}$ and $\mathrm{Cd}^{2+}$ are clearly higher compared to $\mathrm{Mg}^{2+}$ by (on average) about 0.7 and 0.9 log units, respectively, which agrees with the position of $\mathrm{Mn}^{2+}$ within the Irving-Williams series (see Fig. 2). The slightly higher stability of the $\mathrm{Cd}^{2+}$ complexes compared to the corresponding $\mathrm{Mn}^{2+}$ complexes is well in accord with the Stability Ruler of Martin [123-125]. The accumulated data in Tables 2 and 3 shows that the different nature of a metal ion can have an effect in the same order as that of a further phosphate group, e.g. $\log K_{\mathrm{Mg}(\mathrm{ATP})_{\mathrm{op}}}^{\mathrm{Mg}} \approx$ $\log K_{\mathrm{Cd}(\mathrm{ADP})_{\text {op }}}^{\mathrm{Cd}}$

(iii) Macrochelate formation, i.e. the additional coordination of the phosphate-bound metal ion to the N7 position of the purine-moiety (equation (2)), is more distinct with guanine than with adenine (Tables 2 and 3). This is well known [126] and most likely due to the fact that the carbonyl O6 may participate via an outersphere interaction in metal ion binding (Fig. 3) $[122,126,127]$. In contrast, the exocyclic $\mathrm{N} \mathrm{H}_{2}$ group of the adenine nucleobase is known to have an inhibiting effect on metal ion coordination at its N7 position [128]. It should be noted in this context that (in contrast to earlier conclusions [126]) the basicity of N7 in guanine and adenine residues is comparable, i.e. for 9-methylguanine $\mathrm{p} K_{\mathrm{H}(9 \mathrm{MeG})}^{\mathrm{H}}=3.11 \pm 0.06$ and for 9methyladenine $\mathrm{p} k_{\mathrm{H} \cdot \mathrm{N} 7-9-\mathrm{MeA}-\mathrm{N} 1}^{\mathrm{H}}=2.96 \pm 0.10$ (micro acidity constant) [129]. 
(iv) In the case of the adenine complexes $\mathrm{M}(\mathrm{AXP})^{(\mathrm{y}-2)-}$, the extent of macrochelate formation is within the error limits independent of the number of phosphate groups present at the 5 '-end of the nucleoside. This parity in the extent of macrochelate formation occurs despite the fact that the absolute stabilities of the complexes differ drastically. The same observation is made with the $\mathrm{Mg}^{2+}$ and $\mathrm{Ca}^{2+}$ complexes of the guanosine derivatives. However, for the $\mathrm{Mn}^{2+}$ complexes the order $\mathrm{GMP}^{2-} \approx \mathrm{GDP}^{3-}<\mathrm{GTP}^{4-}$ and for the $\mathrm{Cd}^{2+}$ complexes the order $\mathrm{GDP}^{3-}<\mathrm{GMP}^{2-} \approx \mathrm{GTP}^{4-}$ is found. In the latter cases, the differences are small but most likely they are real and they might be a reflection of the various degrees of outersphere complexation $[104,113,126]$.

(v) The four metal ions discussed have clearly different abilities to form macrochelates: A comparison shows that $\mathrm{Ca}^{2+}$ forms only very small amounts of macrochelates (if at all). $\mathrm{Mg}^{2+}$ and $\mathrm{Mn}^{2+}$ are comparable in their affinity towards $\mathrm{N} 7$ of adenine and both have a moderate binding tendency with formation degrees of up to $20 \%$ for the $\mathrm{M}(\mathrm{NXP})_{\mathrm{cl}}^{(\mathrm{y}-2)-}$ species. With guanine, $\mathrm{Mn}^{2+}$ shows a higher affinity towards $\mathrm{N} 7$ than $\mathrm{Mg}^{2+}$, which is probably due to more innersphere binding of $\mathrm{Mn}^{2+} \cdot \mathrm{Cd}^{2+}$ clearly is the best suited metal ion for macrochelate formation with all purine nucleotides with formation degrees of about $50 \%$ or more.

Having discussed the structures of metal ion complexes of mononucleotides in solution and the differences posed by the four mentioned metal ions, it will now be interesting to see if these features are also reflected in the solid state structures of such complexes.

\subsubsection{Insights from crystallography}

There are quite a number of crystal structures of mononucleotides, which have been excellently reviewed by Aoki $[130,131]$. Most of these structures contain $\mathrm{Na}^{+}$as a metal ion, and thus shall not be discussed here as we are concentrating again on the four metal ions $\mathrm{Mg}^{2+}, \mathrm{Ca}^{2+}, \mathrm{Mn}^{2+}$, and $\mathrm{Cd}^{2+}$.

Several structures of nucleoside 5'-monophosphates are available with $\mathrm{Cd}^{2+}$ and $\mathrm{Ca}^{2+}$, e.g. 
of $\mathrm{Cd}^{2+}$ with $\mathrm{CMP}^{2-}$ and $\mathrm{dCMP}^{2-}[132-134]$, which are of a polymeric nature: In all cases $\mathrm{Cd}^{2+}$ shows at least two innersphere contacts (plus one or more outersphere interactions) to a phosphate group (Fig. 4A). A further prominent site of innersphere coordination is the N3 nitrogen of the pyrimidine moiety (Fig. 4A), which is usually not available for metal ion binding in double-stranded nucleic acids as it is involved in hydrogen bonding. Interestingly, only innersphere but no outersphere interaction to $\mathrm{N} 3$ can be observed in any of the $\mathrm{Cd}^{2+}$ structures. In contrast, the carbonyl oxygen $\mathrm{O} 2$ shows no discrimination between a direct coordination or binding via a water molecule to the $\mathrm{Cd}^{2+}$ ion.

Similar observations have been made with $\mathrm{UMP}^{2-}, \mathrm{dUMP}^{2-}$, or $\mathrm{dTMP}^{2-}$ and $\mathrm{Cd}^{2+}$ $[135,136]$ or $\mathrm{Ca}^{2+}[137,138]:$ Again, at least two innersphere and two outersphere contacts of the $\mathrm{Cd}^{2+}$ (or $\mathrm{Ca}^{2+}$ ) to phosphate oxygens are present. Surprisingly at first sight, no interactions are observed with the two carbonyl oxygens, $\mathrm{O} 2$ and $\mathrm{O} 4$. As the $\mathrm{N} 3$ position in uracil or thymine is blocked by a proton, this finding is a strong indication that the $\mathrm{Cd}^{2+}\left(\mathrm{OH}_{2}\right) \cdots \mathrm{O}=\mathrm{C}$ interactions (either inner- or outersphere) are weak, and can be observed only, when the much stronger $\mathrm{Cd}^{2+} \cdots \mathrm{N} 3$ bond is formed as is the case with cytosine where also additional chelate formation results $[139,140]$.

$\mathrm{GMP}^{2-}$ has been crystallized in the presence of $\mathrm{Mn}^{2+}[141,142]$ or $\mathrm{Cd}^{2+}$ [127]. In both cases, the metal ion is bound to the N7 position by innersphere coordination (unfortunately, in the case of the MnGMP structure no coordinates are available for a more detailed interpretation). The five water ligands of the octahedral $\mathrm{Cd}^{2+}$ ion, which is coordinated to N7 (Fig. 3), show an extensive hydrogen bonding network to seven (!) phosphate oxygens, as well as to the $\mathrm{O} 6, \mathrm{~N} 1 \mathrm{H}$ and $\mathrm{N}_{2} \mathrm{H}_{2}$ sites of the guanine nucleobase [127].

The $\mathrm{Cd}^{2+}$ structures discussed above confirm the findings from the solution studies described in Section 3.1.2 that this metal ion shows indeed a high affinity towards nitrogen sites. Nevertheless, the innersphere coordination to phosphate groups in the case of the pyrimidine 5'-monophosphate systems as well as the extensive network of outersphere 
interactions to several phosphate residues in the GMP system demonstrate the high affinity between phosphate moieties and $\mathrm{Cd}^{2+}$.

$\mathrm{ATP}^{4-}$ has been crystallized several times with $\mathrm{Mg}^{2+}[143-145]$ and $\mathrm{Ca}^{2+}[143-145]$ and once each with $\mathrm{Mn}^{2+}$ [146] and $\mathrm{Cd}^{2+}$ [145] and should thus provide an ideal basis for a comparison of the coordination tendencies of these four metal ions. However, all structures are virtually identical as a superposition of the nucleotide and the metal ions demonstrates (not shown). A fully dehydrated metal ion bridges the triphosphate chains of two ATP ${ }^{4-}$ molecules thereby coordinating to every phosphate group (Fig. 4B). The second metal ion present in the crystal structures is in its hexahydrate form showing an extensive hydrogen bonding network to further phosphate groups, a sugar residue, as well as a water molecule. Obviously this finding is not in perfect agreement with the results of the solution studies. While both methods demonstrate that the triphosphate group is the primary binding site, the solution studies show in addition a discrimination between the various metal ions in their tendency towards macrochelate formation with N7. A reason for this discrepancy is certainly the effect of crystal packing, as hydrogen bonding between pairs of adenine nucleobases as well as between the adenine moieties and neighboring triphosphate groups is observed. In addition, stacking interactions between the adenine nucleobase and heteroaromatic amines, like 2,2'-dipyridylamine used during crystallization, are observed. All these interactions are likely to shield the purine nucleobase from additional metal ion interactions, as observed in solution.

To summarize, some crystal structures of metal ion complexes with mononucleotides confirm nicely the results from solution studies, others do so to a lesser extent. In general, there are only very few structures available of complexes formed with different metal ions and the most common nucleotides. Consequently, this makes it difficult (or actually impossible) to draw definite conclusions from such comparisons. It is evident that it would be very advantageous to obtain more such structures of complexes, crystallized under different 
conditions.

\subsection{Metal ion binding to dinucleotides}

The mononucleotides discussed in Section 3.1 distinguish themselves from the situation in nucleic acids that they have no bridging phosphate diester group with only a single negative charge. One of the simplest systems which contains such a phosphate diester is certainly a dinucleotide. The direct determination of stability constants of metal ion complexes formed with such a bridging phosphate is very difficult because no competition for binding occurs between protons and metal ions within the experimentally accessible $\mathrm{pH}$ range for potentiometric $\mathrm{pH}$ titrations. This means that in the physiological $\mathrm{pH}$ range the phosphate unit is in principle freely accessible for metal ions [147,148]. To the best of our knowledge only two studies exist that quantify the coordination of $\mathrm{M}^{2+}$ ions to a bridging phosphate $[148,149]$. These two studies with $\mathrm{pUpU}^{3-}$ and $\mathrm{d}(\mathrm{pGpG})^{3-}$ (Fig. 5) that contain both an additional 5'terminal phosphate group, therefore also quantify the simultaneous coordination of one metal ion to two neighboring phosphate units, which is a key feature of ribozyme structure and function.

Naturally, binding equilibria of metal ions with dinucleotides are more complicated than with mononucleotides. The 5'-terminal phosphate group remains the primary binding site due to its twofold negative charge. In case of the dinucleotide $\mathrm{d}(\mathrm{pGpG})^{3-}$ this leads to the species $\mathrm{M}[\mathrm{d}(\mathrm{pGpG})]_{\mathrm{op}}^{-}$. For a metal ion bound to the terminal phosphate group of a purine dinucleotide, two possibilities for further coordination within the molecule are feasible: As depicted in equilibrium (8),

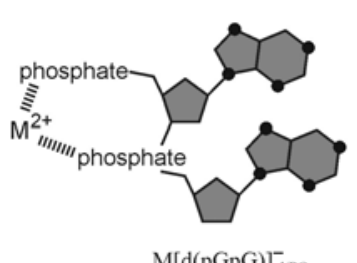

$M[d(p G p G)]^{-}$
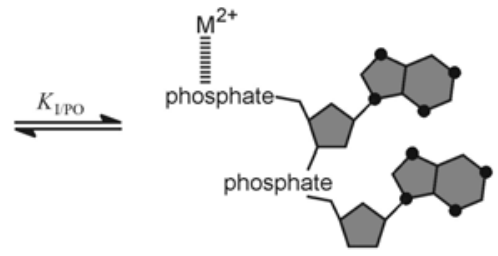

$\mathrm{M}[\mathrm{d}(\mathrm{pGpG})]_{\mathrm{n}}^{-}$

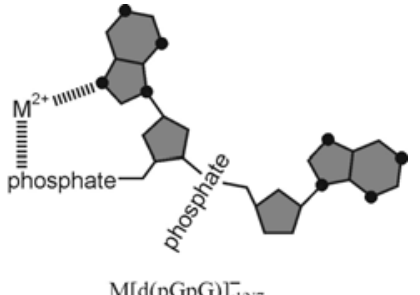


the metal ion can additionally coordinate either to the bridging phosphate group, resulting in $\mathrm{M}[\mathrm{d}(\mathrm{pGpG})]_{\mathrm{c} / \mathrm{PO}}^{-}$, or to the $\mathrm{N} 7$ position of the same nucleotide, yielding $\mathrm{M}[\mathrm{d}(\mathrm{pGpG})]_{\mathrm{c} / \mathrm{N} 7}^{-}$ [149]. For coordination to $\mathrm{pUpU}^{3-}$ only macrochelate formation with the bridging phosphate group is possible, i.e. the left side of equilibrium (8), as pyrimidine nucleobases in their dominating anti conformation offer no additional binding site for a 5'-phosphate bound metal ion $[117,148]$.

It should be noted that the two corresponding equilibrium constants $K_{\mathrm{I} / \mathrm{PO}}$ and $K_{\mathrm{I} / \mathrm{N} 7}$ are dimensionless and therefore macrochelate formation is again independent of complex concentration. It is obvious that in cases like $\mathrm{d}(\mathrm{pGpG})^{3-}$, a competition is taking place between the bridging phosphate and the N7 nitrogen of the 5'-nucleotide for binding of the second site. The extent to which one of the two internal equilibriums is favored over the other is therefore only dependent on the nature of the metal ion, i.e. its preference for an oxygen or nitrogen donor site, respectively.

Metal ion coordination to $\mathrm{pUpU}^{3-}$ can be used to quantify the ability of different metal ions to bridge the two phosphate groups in any dinucleotide and has been investigated with $\mathrm{Mg}^{2+}, \mathrm{Mn}^{2+}, \mathrm{Cd}^{2+}, \mathrm{Zn}^{2+}$, and $\mathrm{Pb}^{2+}:$ Out of these five metal ions, $\mathrm{Mg}^{2+}, \mathrm{Mn}^{2+}$, and $\mathrm{Cd}^{2+}$ all show the same slight stability increase of $\log \Delta=0.24 \pm 0.04(3 \sigma)$, which is solely due to the additional negative charge within the molecule compared to $\mathrm{UMP}^{2-}[148]$. Therefore, none of these three metal ions forms macrochelated species or only traces thereof. This is different with $\mathrm{Zn}^{2+}$ and $\mathrm{Pb}^{2+}$. About $25 \%$ of the $\mathrm{Zn}^{2+}$-complex is present as the closed species $\mathrm{Zn}[\mathrm{pUpU})]_{\mathrm{cl} / \mathrm{PO}}^{-}(\log \Delta=0.37 \pm 0.07(3 \sigma))$ and in case of $\mathrm{Pb}^{2+}$ about $93 \%$ is in the macrochelated form $(\log \Delta=1.40 \pm 0.26(3 \sigma))$ [148]. These results are actually well in line with the Stability Ruler proposed by Martin [123-125] for the interaction of metal ions with simple oxygen donors such as oxalate and thus they illustrate further already at this point that a "scale-up" of such observations from small to larger molecules is possible and also valid. 
For the complexes $\mathrm{M}[\mathrm{d}(\mathrm{pGpG})]^{-}\left(\mathrm{M}^{2+}=\mathrm{Mg}^{2+}, \mathrm{Zn}^{2+}, \mathrm{Cd}^{2+}\right.$, and $\left.\mathrm{Pb}^{2+}\right)$ macrochelate formation can be observed in all systems [149]. $\mathrm{Mg}^{2+}$ and $\mathrm{Cd}^{2+}$ both form exclusively the N7 coordinated macrochelate $\mathrm{M}[\mathrm{d}(\mathrm{pGpG})]_{\mathrm{c} / \mathrm{N} 7}^{-}$with surprisingly high formation degrees of about $72 \%$ and $94 \%$, respectively [149]. These formation degrees are somewhat larger than those observed for the corresponding $\mathrm{M}(\mathrm{GMP})$ and $\mathrm{M}(\mathrm{dGMP})$ species $[122,150]$. A possible reason for this result is most likely a partial preorientation of the dinucleotide due to an intramolecular guanine-guanine stack occurring in $\mathrm{d}(\mathrm{pGpG})^{3-}$ (see Section 3.3). In accord herewith is the slightly smaller formation degree of the $\mathrm{Pb}[\mathrm{d}(\mathrm{pGpG})]_{\mathrm{cl} / \mathrm{PO}}^{-}$species compared to $\mathrm{Pb}[\mathrm{pUpU})]_{\mathrm{cl} / \mathrm{PO}}^{-}$(see below) as the base-stacking is expected to inhibit the flexibility of the dinucleotide needed for the formation of the 10-membered phosphate-phosphate chelate. It is very well feasible that such a preorientation via nucleobase stacking (and other interactions like hydrogen bonding) is very important for the formation of a metal ion binding pocket in larger nucleic acids (for a more detailed discussion see Section 3.3).

It should be noted that for the above mentioned $\mathrm{M}[\mathrm{d}(\mathrm{pGpG})]_{\mathrm{cl} / \mathrm{N} 7}^{-}$complexes, a distinction between innersphere and outersphere binding is not possible, the latter being expected to occur especially with $\mathrm{Mg}^{2+}$. $\mathrm{Zn}^{2+}$ forms to a large extent the N7-bound species $\mathrm{Zn}[\mathrm{d}(\mathrm{pGpG})]_{\mathrm{cl} / \mathrm{N} 7}^{-}$as well, but additionally, also a lower percentage of the bridged bisphosphate chelate $\mathrm{Zn}[\mathrm{d}(\mathrm{pGpG})]_{\mathrm{cl} / \mathrm{PO}}^{-}$is present [149]. In combination with the data from $\mathrm{pUpU}^{3-}$ the conclusion seems justified that as soon as a N7 site is available for coordination, $\mathrm{Zn}^{2+}$ prefers this ring nitrogen over a second phosphate binding. Again, $\mathrm{Pb}^{2+}$ shows a very high affinity towards oxygen donor ligands and consequently, the phosphate bridged complex $\mathrm{Pb}[\mathrm{d}(\mathrm{pGpG})]_{\mathrm{c} / \mathrm{PO}}^{-}$is exclusively observed with a formation degree of $84 \pm 6 \%$ [149]. Most likely this overwhelming preference for phosphate binding over N7 coordination is also true for $\mathrm{Ca}^{2+}[149,151]$. This would mean that $\mathrm{Mg}^{2+}$ and $\mathrm{Ca}^{2+}$ show a rather different binding behavior towards neighboring phosphate groups leading to different binding environments 
and consequently also to possible local structural changes which might also effect catalysis something which is indeed observed in group II intron ribozymes (see Section 2) [8,52].

As shown above for mononucleotides, the phosphate residue behaves identically in its binding property to each metal ion irrespective of the nucleobase attached to the (deoxy)ribose moiety (Tables 2 and 3), i.e. every metal ion exhibits its specific binding affinity dependent on its preference for oxygen ligands and its position in the Periodic Table. In contrast, the two dinucleotides $\mathrm{pUpU}^{3-}$ and $\mathrm{d}(\mathrm{pGpG})^{3-}$, and most likely also others, behave differently: The coordinating properties of metal ions towards two neighboring phosphate groups depend on their affinity for oxygen ligands (compare the left part of equilibrium (8)) and consequently different local structures can be formed even without the direct participation of nucleobases as binding sites.

\subsection{The effect of structural preorientation in dinucleotides on metal ion binding}

Aside from interactions with metal ions, the structures of large and complex RNAs (and DNAs) are majorily determined by internucleotide interactions like hydrogen bonding and stacking between the aromatic nucleobase moieties. As stacking interactions between purines are much stronger than between pyrimidines [152-155], one may expect that in the dinucleotide $\mathrm{d}(\mathrm{pGpG})^{3-}$ some orientation between the two guanine planes occurs, whereas in $\mathrm{pUpU}^{3-}$ such stacking interactions are expected to be absent (or much smaller) $[152,153]$. Such an orientation between the two nucleotide units should also affect the relative positioning of the two phosphate groups to each other as well as the positions of the N7 sites in relation to the phosphate moieties. It will now be interesting to see, if in some way such an orientation is reflected in the strengths of metal ion binding, i.e. macrochelate formation as expressed in equilibrium (8). Naturally, such insights into the question of a possible preorientation are of relevance for nucleic acid structures and the coordination of a metal ion at a specific site. 
For the evaluation of such effects regarding the orientation of subunits in space, one needs to compare the charge-corrected stability enhancements due to macrochelate formation (equilibrium (8)) for the $\mathrm{M}[\mathrm{d}(\mathrm{pGpG})]^{-}$complexes [149] with those of the corresponding M(dGMP) species [150] (available for $\mathrm{M}^{2+}=\mathrm{Mg}^{2+}, \mathrm{Zn}^{2+}$ or $\mathrm{Cd}^{2+}$; the required data are summarized in Table 4) $[122,149,150,156]$. Indeed, there is clearly an extra stability enhancement for the $\mathrm{M}[\mathrm{d}(\mathrm{pGpG})]^{-}$complexes, which amounts on average to $\Delta \log \Delta_{\mathrm{M} / \mathrm{d}(\mathrm{pGpG}) / \mathrm{dGMP} / \mathrm{av}}^{*}=\log \Delta_{\mathrm{M} / \mathrm{d}(\mathrm{pGpG}) / \mathrm{cor}}^{*}-\log \Delta_{\mathrm{M} / \mathrm{dGMP}}=0.31 \pm 0.07$ (Table 4, column 5). One may now attribute this "extra" stability enhancement to a preorientation of the $\mathrm{d}(\mathrm{pGpG})^{3-}$ ligand, i.e. an intramolecular head-to-head stacking between the two purine moieties. This stacking arrangement would then facilitate macrochelate formation of the metal ion coordinated at the terminal phosphate group with the N7 site of the same dG. Even an additional coordination to the 3'-neighboring dG might be feasible, probably (partly) in an outersphere manner. Indeed, such a "three-point interaction" is sterically possible as the results for $\mathrm{Mg}^{2+}$ coordination in the ribosome demonstrate (see Section 4.1 and Fig. 7B).

If the above assumption of a preorientation for the $\mathrm{d}(\mathrm{pGpG})^{3-}$ ligand in solution is correct, then the formation of a phosphate-phosphate macrochelate upon $\mathrm{M}^{2+}$ coordination, $\mathrm{M}[\mathrm{d}(\mathrm{pGpG})]_{\mathrm{cl} / \mathrm{PO}}^{-}$, should be inhibited because of the loss of flexibility in the phosphate backbone. This is indeed the case as a comparison of the charge-corrected stability enhancements due to the formation of the 10 -membered chelates in $\mathrm{Pb}(\mathrm{pUpU})^{-}$and $\mathrm{Pb}[\mathrm{d}(\mathrm{pGpG})]^{-}$shows $[148,149]: \log \Delta_{\mathrm{Pb} / \mathrm{d}(\mathrm{pGpG}) / \mathrm{cor}}^{*}-\log \Delta_{\mathrm{Pb} / \mathrm{pUpU} / \mathrm{cor}}^{*}=(0.79 \pm 0.14)-(1.16 \pm 0.26)=-0.37 \pm 0.30$ $(3 \sigma)$. The absolute value of this negative stability difference is in perfect agreement with the positive one obtained above, $\Delta \log \Delta_{\mathrm{M} / \mathrm{d}(\mathrm{pGpG}) / \mathrm{dGMP} / \mathrm{av}}^{*}$, for $\mathrm{Mg}^{2+}, \mathrm{Zn}^{2+}$, and $\mathrm{Cd}^{2+}$. Hence, the summarized observations indicate that some intramolecular purine-purine stacking in $\mathrm{d}(\mathrm{pGpG})^{3-}$ occurs, at least in the presence of metal ions.

At first glance, this seems to be in contrast with recent reasonings [147] based on 
comparisons of the acid-base properties of this dinucleotide in the absence of metal ions: The difference in acidity of the two $\mathrm{N} 1 \mathrm{H}$ sites in $\mathrm{d}(\mathrm{pGpG})^{3-}$ of $\Delta \mathrm{p} K_{\mathrm{a}}=0.57 \pm 0.16(3 \sigma)$, which is within the error limits identical with the statistically expected value of 0.6 for a symmetrical diprotonic acid [157], let to the conclusion that the two nucleotide units in $\mathrm{d}(\mathrm{pGpG})^{3-}$ "react rather independently and do not 'feel' much of each other". In other words, $\mathrm{d}(\mathrm{pGpG})^{3-}$ occurs predominately in an open, unstacked form. The larger acidity difference determined for $\mathrm{d}(\mathrm{GpG})^{-}\left(\Delta \mathrm{p} K_{\mathrm{a} / \mathrm{N} 1 \mathrm{H}}=1.02 \pm 0.08\right)$ was thereby explained by intramolecular stacking interactions, which are inhibited by the twofold negatively charged 5'-phosphate group in $d(p G p G)^{3-}[147]$. This comparison of the acid-base properties of $d(p G p G)^{3-}$ and $d(G p G)^{-}$now implies that the neutralization of this negative charge by metal ion coordination at the terminal phosphate group restores the stacking abilities of the two guanine nucleobases.

Whether some preorientation of the nucleobase residues already exists within the $\mathrm{d}(\mathrm{pGpG})^{3-}$ species or only occurs after metal ion coordination, i.e. formation of the $\mathrm{M}[\mathrm{d}(\mathrm{pGpG})]_{\text {op }}^{-}$species (equilibrium (8)), cannot be answered unequivocally because all the differences considered are small and often also close to the error limits $[147,149]$. Nevertheless, one can estimate the extreme situation of such a preorientation: If the above 0.3 $\log$ units $\left(=\Delta \log \Delta_{\mathrm{M} / \mathrm{d}(\mathrm{pGpG}) / \mathrm{dGMP} / \mathrm{av}}^{*}\right)$ would be completely due to intramolecular stacking either in $\mathrm{d}(\mathrm{pGpG})^{3-}$ and/or in $\mathrm{M}[\mathrm{d}(\mathrm{pGpG})]_{\text {op }}^{-}$, this would equal a formation degree of $50 \%$ for the stacked species (see Table 4, footnote 'd'). On the other hand, a significant amount of this enhancement is certainly due to the "three-point" macrochelation also indicated above which naturally further facilitates the intramolecular stacking interaction. It is thus evident that any preorientation in $\mathrm{d}(\mathrm{pGpG})^{3-}$ and in $\mathrm{M}[\mathrm{d}(\mathrm{pGpG})]_{\text {op }}^{-}$as well as the interaction of a phosphatecoordinated metal ion with both N7 sites are very much interwoven with each other and hard to separate because they promote each other.

To conclude, if one assumes that only 0.1 or $0.15 \mathrm{log}$ units of the total extra stability 
enhancement $\Delta \log \Delta_{\mathrm{M} / \mathrm{d}(\mathrm{pGg}) / \mathrm{dGMP} / \mathrm{av}}^{*}$ originates from the intramolecular stack, this corresponds already to formation degrees of the preoriented structure of about 20 or $30 \%$, respectively [156]. Equally important, these formation degrees are connected with only very tiny changes in free energy of $\Delta \mathrm{G}_{\left(25^{\circ} \mathrm{C}\right)}^{0}=-0.57$ or $-0.86 \mathrm{kJmol}^{-1}$, respectively [156]. Hence, we are convinced that indeed small but significant amounts of $\mathrm{d}(\mathrm{pGpG})^{3-}, \mathrm{M}[\mathrm{d}(\mathrm{pGpG})]_{\mathrm{op}}^{-}$, and even more of $\mathrm{d}(\mathrm{GpG})^{-}$[147], exist in the described preorientated stacked form thus facilitating the "three-point" metal ion binding (and/or vice versa). It is evident that in larger RNA molecules such preorientations are achieved more easily and that this gives rise to preferred sites for metal ion binding as observed, e.g., with $\mathrm{Mg}^{2+}$ in group II introns [21] or the ribosome [19] (see also Section 4.1).

\section{Metal ion binding to ribozymes and DNA}

Having established and summarized in Section 3 the different metal ion binding properties of mono- and dinucleotides and the structures of their complexes, it will now be interesting to see if parallels can be drawn to existing data of larger nucleic acids. To the best of our knowledge no detailed structural solution data on the atomic level exists showing the complete binding geometries of metal ions in their binding pockets (perhaps with the exception of DNA quadruplexes [158]) [7]. In the following sections we therefore rely on high resolution solid state structures of large RNA molecules determined by X-ray crystallography. Because a complete evaluation of the existing structures in the PDB/NDB would go beyond the scope of this review, we concentrate on two types of RNA and one DNA sequence, i.e. the large ribosomal subunit, the HIV-1 dimerization initiation site (DIS), and the so-called Dickerson-Drew DNA dodecamer. Nevertheless, it needs to be emphasized that the conclusions drawn here will hold for all complex RNA structures, as in all instances innersphere and outersphere binding of the metal ions occurs, as e.g. can also be seen in the 
P4-P5-P6 domains of the Tetrahymena group I intron (Fig. 6).

\section{1. $\mathrm{Mg}^{2+}$ binding to the ribosome}

The ribosomal RNA-protein complex represents the largest nucleic acid structure determined by X-ray crystallography today [2-4]. The large ribosomal subunit of Haloarcula marismortui at a resolution of $2.1 \AA$ was additionally analyzed by Klein et al. with respect to its metal ion binding sites [19]. Aside from 88 binding sites for monovalent cations, which will not be discussed here, 116 positions for $\mathrm{Mg}^{2+}$ ions have been localized. This ribosome structure therefore represents an ideal basis for investigating the different $\mathrm{Mg}^{2+}$ binding modes within a complex RNA architecture.

The 50S subunit of $H$. marismortui comprises 3045 nucleotides (2833 of which could be refined in the crystal structure) [2] and consequently an equal number of negative charges originating from the phosphate groups need to be compensated by metal ions. As the 116 $\mathrm{Mg}^{2+}$ and $88 \mathrm{Na}^{+} / \mathrm{K}^{+}$ions identified in the structure add up to 320 positive charges, only $10.6 \%$ of the phosphodiester-bridge charges are compensated by these metal ions. Neglecting any further positive charges contributed by the proteins bound, it is obvious that the $\mathrm{Mg}^{2+}$ ions identified in the structure represent only the small fraction of divalent metal ions which are relatively tightly bound. Such a more or less tight fixation in a certain coordination environment is a strong indication for site specific binding.

Out of the $116 \mathrm{Mg}^{2+}$ ions, 30 bridge protein with RNA residues and only two are exclusively bound to protein sites. Considering that the ratio between RNA and proteins in the 50S subunit amounts to $66: 34(\mathrm{w} / \mathrm{w})$, this shows that RNA is obviously the primary target for hard metal ions like $\mathrm{Mg}^{2+}$. Another interesting aspect is that again out of the 116 ions, only nine are bound exclusively by outersphere interactions (Fig. 6B and Fig. 7A) - all others show at least one innersphere coordination and 30 of the $\mathrm{Mg}^{2+}$ ions coordinate even directly to three or more sites (Fig. 7). Only one $\mathrm{Mg}^{2+}$ seems to be fully dehydrated! From the nine 
outersphere bound $\mathrm{Mg}^{2+}$ ions, three form hydrogen bonds from their first shell water molecules to nucleobase moieties only (Fig. 7A), whereas the other six ions all show contacts to a phosphate oxygen and five of them also to nucleobases or amino acids. Taken together, this is a first indication that the phosphate group is the primary binding site and that contacts to a nucleobase (or phosphate) can be well mediated through outersphere interactions.

As a consequence of the above mentioned numbers in combination with the observation that only five $\mathrm{Mg}^{2+}$ ions are coordinated exclusively to nucleobase atoms, two $\mathrm{Mg}^{2+}$ ions to proteins and another three only to functional groups of the nucleosides and/or amino acids, the overwhelming majority of the 106 magnesium(II) ions is bound to phosphate groups. The phosphate groups also comprise the majority of innersphere binding sites: From the total of $107 \mathrm{Mg}^{2+}$ ions being coordinated through at least one innersphere contact, $82(=76.6 \%)$ show a minimum of one of these direct contacts to a non-bridging oxygen atom of the phosphate groups (Fig. 7). Out of these 82 ions, $45 \mathrm{Mg}^{2+}$ bridge two or more phosphate groups by innersphere coordination, and another 33 by at least one innersphere and one or more outersphere contacts. Again, the observation that phosphate groups are the primary binding site for $\mathrm{Mg}^{2+}$ (and other alkaline earth, divalent 3d-transition ions as well as $\mathrm{Zn}^{2+}$ or $\mathrm{Cd}^{2+}$ ) in nucleic acids is very well in line with the solution studies described in Section 3, and it also shows that $\mathrm{Mg}^{2+}$ is bound to phosphate oxygens to a large part (but not exclusively) through innersphere coordination.

The potentiometric $\mathrm{pH}$ titrations with mononucleotides show that a metal ion bound to the 5'-terminal phosphate group(s) may undergo additional contacts with the nucleobase, i.e. macrochelates are formed (equilibrium (2)), whose degree of formation is strongly dependent on the kind of metal ion. Can macrochelate formation or simultaneous phosphate-nucleobase coordination also be observed in the ribosome? Considering the 106 phosphate-bound $\mathrm{Mg}^{2+}$ cations, the following binding patterns regarding potential macrochelate formation are found:

(i) $21 \mathrm{Mg}^{2+}$ are bound to $-\mathrm{OP}(\mathrm{O})_{2}^{-} \mathrm{O}$ - units exclusively (Fig. 7D). This is a surprisingly 
high number (about 20\%) considering the huge amount of alternative binding sites in potentially close proximity to a $\mathrm{Mg}^{2+}$ in a complicated architecture like the ribosome.

(ii) $48 \mathrm{Mg}^{2+}$ are bound to at least one phosphate moiety and any one $\mathrm{N} 7$ position, corresponding to a "macrochelate-formation" degree of 45\% (Fig. 7B and C). Interestingly, 30 of those 48 contacts are actually intra-nucleotide macrochelates, i.e. the phosphate and the N7 position belong to the same nucleotide unit. This corresponds to a formation degree of $28 \%$ for intra-nucleotide macrochelates (based on the total $106 \mathrm{Mg}^{2+}$ being bound to phosphate groups), which is extraordinarily close to the one found for the mononucleotide $\mathrm{GMP}^{2-}(31 \pm$ $7 \%$, see also Table 2) as determined by potentiometric $\mathrm{pH}$ titrations [122].

(iii) Out of the $48 \mathrm{Mg}^{2+}$ ions that show a simultaneous phosphate/N7 coordination, 28 exhibit an inter-nucleotide macrochelate between two consecutive nucleotides, thus some $\mathrm{Mg}^{2+}$ ions are involved in both intra- and inter-macrochelate formation. It is most interesting to note that out of these $28 \mathrm{Mg}^{2+}, 27$ bind to the $\mathrm{N} 7$ position of the purine nucleotide that is positioned 3' to the nucleotide of the coordinated phosphate $\left(-\mathrm{PO}_{4}^{-}-{ }_{n} / \mathrm{N}_{\mathrm{n}+1}\right)$, and only one shows a binding pattern of the opposite way, i.e. $\left(\mathrm{N}_{\mathrm{n}} /-\mathrm{PO}_{4}^{-}-{ }_{\mathrm{n}+1}\right)$. On first sight this is surprising, as the binding sites of the latter $\mathrm{N}_{\mathrm{n}} /-\mathrm{PO}_{4}^{-}{ }_{\mathrm{n}+1}$ coordination pattern seem to be closer in distance, but most probably steric constraints are the reason for this clear discrimination. A "three-point" macrochelation as discussed in Section 3.3, also occurs: Out of the 28 above mentioned $\mathrm{Mg}^{2+}$ ions, 11 show a $-\mathrm{PO}_{4}^{-}-{ }_{\mathrm{n}} / \mathrm{N}_{\mathrm{n}} /-\mathrm{PO}_{4}^{-}{ }_{{ }_{\mathrm{n}}+1}$, and 13 ions a $-\mathrm{PO}_{4}^{-}-{ }_{\mathrm{n}} /-\mathrm{PO}_{4}^{-}{ }_{n+1} / \mathrm{N} 7_{\mathrm{n}+1}$ coordination pattern (note that no distinction between outer- and inner-sphere coordination is done here). Hence, dinucleotides like $\mathrm{d}(\mathrm{pGpG})^{3-}$, as discussed in Section 3.2, constitute perfect model compounds to investigate the various binding patterns. In fact, the high occurrence of the $-\mathrm{PO}_{4}^{-}-{ }_{n} / \mathrm{Z} / \mathrm{N} 7_{\mathrm{n}+1} \mathrm{Mg}^{2+}$ coordination pattern $(\mathrm{Z}=$ $-\mathrm{PO}_{4}^{-}{ }_{n+1}$ or $\mathrm{N}_{\mathrm{n}}$ ) suggests that this is a favored metal ion binding motif in RNAs if one considers matters on the atomic coordination chemical level. 
(iv) Besides the N7 position, also the carbonyl O6 of guanines is a potential site for macrochelate formation (Fig. 7B). Indeed, in 19 cases (out of the above mentioned 30), simultaneous intra-nucleobase coordination to N7 and O6 takes place, whereby in all cases at least one water molecule is involved. There are only five instances where solely O6 (but not N7) is coordinated, but the O6 never belongs to the same nucleotide as the coordinated phosphate oxygen. The same is true for macrochelate formation involving the $\mathrm{O} 4$ and $\mathrm{O} 2$ positions of pyrimidine bases. In the latter case also no simultaneous coordination to a N7 position of a nearby purine base can be found. It is also interesting to note that no preference for inner- or outersphere binding to either N7 or carbonyl oxygens can be recognized.

The above listed points based on X-ray crystallographic studies of a large RNA confirm the results from solution studies for $\mathrm{Mg}^{2+}$ binding to nucleic acids (Section 3) with a remarkable accuracy: (i) Intra-nucleotide macrochelate formation is in the same order, (ii) the possibility of simultaneous N7 and O6 binding is observed as it has been proposed for nucleotides before $[104,122,126]$, and (iii) no intra-residue coordination to the phosphate group and a carbonyl oxygen of pyrimidine-nucleotide units occurs. To summarize, the structural insight into the ribosome constitutes a very nice example that allows to validate the results from solution studies and to extrapolate even better in the future the data from mononucleotides to larger RNA structures.

\section{2. $\quad$ Metal ion binding to the HIV dimerization initiation site}

In the above Section 4.1. the coordination properties of $\mathrm{Mg}^{2+}$ ions within a large RNA structure have been analyzed and compared to results from solution studies (Section 3). Keeping in mind the issues raised in the beginning of this review that other metal ions than $\mathrm{Mg}^{2+}$ may lead to completely different phenotypical results in terms of ribozyme reactivity, this section now compares the coordinating properties of $\mathrm{Mg}^{2+}, \mathrm{Ca}^{2+}, \mathrm{Mn}^{2+}$, and $\mathrm{Cd}^{2+}$ to a specific RNA sequence. 
Ideally, for a comparison of the coordinating properties and geometries of the four mentioned metal ions to RNA, four X-ray structures of identical RNA sequences crystallized with each individual metal ion should be available. We are only aware of one example where this has been accomplished to a certain extent: Two related RNA duplexes of the HIV-1 dimerization initiation site (DIS), subtype-A and subtype-B, have been crystallized in the presence of $\mathrm{Mg}^{2+}$ and subsequently soaked or co-crystallized with eleven different metal ions $\left(\mathrm{K}^{+}, \mathrm{Pb}^{2+}, \mathrm{Mn}^{2+}, \mathrm{Ba}^{2+}, \mathrm{Ca}^{2+}, \mathrm{Cd}^{2+}, \mathrm{Sr}^{2+}, \mathrm{Zn}^{2+}, \mathrm{Co}^{2+}, \mathrm{Au}^{3+}, \mathrm{Pt}^{4+}\right)$ [159]. In the present context we will concentrate on $\mathrm{Mg}^{2+}$ in comparison with $\mathrm{Ca}^{2+}, \mathrm{Mn}^{2+}$, and $\mathrm{Cd}^{2+}$ at the individual binding pockets within these RNAs. However, unfortunately only the pdb files of the $\mathrm{Mg}^{2+}$ (PDB IDs 462D and 1Y99) and $\mathrm{Mn}^{2+}$ (PDB ID 1Y90) forms are available allowing us a detailed characterization, whereas for $\mathrm{Ca}^{2+}$ and $\mathrm{Cd}^{2+}$ we can only rely on the content of ref. [159].

Eight specific $\mathrm{Mg}^{2+}$ binding sites were identified in the subtype-A DIS, three of them being identical $\left(\alpha / \alpha^{\prime}, \beta / \beta^{\prime}, \gamma / \gamma^{\prime}\right)$ due to the palindromic sequence, and two being close to each other in the center of the duplex $(\delta, \varepsilon)$ (see also Fig. $8 \mathrm{~A})$. Out of the five unique coordination sites, the coordination sphere of one $\mathrm{Mg}^{2+}$ is not refined $(\varepsilon)$ but seems to be hexahydrated, and two $\mathrm{Mg}^{2+}$ ions $\left(\alpha / \alpha^{\prime}, \beta / \beta^{\prime}\right)$ are fully hexahydrated and bind to the nucleobase functional groups at the major groove edge of GC base pairs only. Two further ions bind near the bulged out adenosine and the adjacent GA base pair $\left(\gamma / \gamma^{\prime}, \delta\right)$, both of them showing two innersphere contacts. The $\mathrm{Mg}^{2+}$ ion in position $\delta$ bridges the phosphate groups of the two strands (Fig. 8A and $8 \mathrm{C})$. The $\gamma / \gamma^{\prime}-\mathrm{Mg}^{2+}$ site is peculiar because in addition to the two innersphere contacts to a A8-phosphate oxygen and the N7 of guanine 10 it shows four further outersphere contacts (partially bifurcated) to nearby O6, N7 sites as well as to one phosphate oxygen (Fig. 8D). Having the evaluation of the $\mathrm{Mg}^{2+}$ binding sites within the ribosome in mind (Section 4.1), it is surprising to see, that in a largely duplex-RNA, the $\mathrm{Mg}^{2+}$ ions seem to bind preferably to 
the functional groups of the nucleotide moieties only in a completely outersphere manner. Only in regions of loops and non-canonical base-pairs innersphere binding and phosphate coordination occurs. The eight $\mathrm{Mg}^{2+}$ ions in the above described HIV-DIS structure approximate a charge compensation of $35 \%$ of the 46 nucleotide long phosphate-sugar backbone (compared to $10.6 \%$ in the ribosome, see Section 4.1 ), but the three $\mathrm{Mg}^{2+}$ that are partially innersphere bound $\left(\gamma / \gamma^{\prime}, \delta\right)$ only compensate for $13 \%$ of the negative charges. It is left for future studies to see if in the ribosome $\mathrm{Mg}^{2+}$ ions bound to the major groove or to regular duplexes were just not detected.

How do the $\mathrm{Mg}^{2+}$ binding sites compare with those of $\mathrm{Mn}^{2+}$ ? Unfortunately the crystal structure of the $\mathrm{Mn}^{2+}$ form does not allow a detailed analysis as no water molecules are included in the refinement (PDB ID 1Y90). Nevertheless, all $\mathrm{Mg}^{2+}$ positions in the subtype-A DIS can be overlaid pretty well with $\mathrm{Mn}^{2+}$ in the crystal structure (Fig. 8B), suggesting that $\mathrm{Mn}^{2+}$ indeed is a good replacement for $\mathrm{Mg}^{2+}$. This conclusion is slightly premature, as the $\mathrm{Mn}^{2+}$ ions also occupy additional sites within this RNA: Two more $\mathrm{Mn}^{2+}$ ions are found at the terminal base pairs of the helix and another one near one bulged out adenosine. A similar situation is found in the subtype- $\mathrm{B}$ duplex, where $\mathrm{Mg}^{2+}$ only partially occupies two sites, but $\mathrm{Mn}^{2+}$ fully occupies a pocket formed by two phosphates and a guanine N7 [159]. One can therefore conclude the following: First, $\mathrm{Mn}^{2+}$ behaves similar to $\mathrm{Mg}^{2+}$ in its preference for certain binding sites, which is in accord with the similar extent of macrochelate formation (Tables 2 and 3), and confirmed by the corresponding occupation of distinct sites, and second, $\mathrm{Mn}^{2+}$ has a slightly higher affinity towards RNA than $\mathrm{Mg}^{2+}$ as the coordination of additional $\mathrm{Mn}^{2+}$ ions suggests, and actually the higher affinity towards mono- and dinucleotides already predicted this behavior. Both points are well in line with the relative positioning of $\mathrm{Mg}^{2+}$ and $\mathrm{Mn}^{2+}$ within the Irving-Williams series and the increasing affinity towards nitrogen ligands when moving further to the right within the $3 \mathrm{~d}$ series in the Periodic Table.

$\mathrm{Ca}^{2+}$ as well as $\mathrm{Sr}^{2+}$ and $\mathrm{Ba}^{2+}$ are poor mimics of $\mathrm{Mg}^{2+}$, as indicated by the fact that none 
of these heavier alkaline earth metal ions occupies the same sites as $\mathrm{Mg}^{2+}$. In fact, the coordination sites of $\mathrm{Ca}^{2+}, \mathrm{Sr}^{2+}$, and $\mathrm{Ba}^{2+}$ are difficult to establish because none is fully occupied. This is actually in line with their larger size, faster ligand exchange rates and lower binding tendencies (Table 1).

$\mathrm{Cd}^{2+}$ is very selective in replacing $\mathrm{Mg}^{2+}$. Only at the $\gamma / \gamma^{\prime}$ site, where a $\mathrm{Mg}^{2+}$ ion makes two innersphere contacts with a phosphate oxygen as well as a guanine $\mathrm{N} 7$ site, also $\mathrm{Cd}^{2+}$ can be localized. No other $\mathrm{Mg}^{2+}$ was replaced in the subtype-A structure including the one at the $\delta$ position where innersphere coordination to two phosphates occurs, although $\mathrm{Cd}^{2+}$ has a much higher intrinsic affinity towards nucleic acids than $\mathrm{Mg}^{2+}$. This observation illustrates that besides the higher affinity, also the coordinating sites, their geometry and accessibility play an important role: $\mathrm{Cd}^{2+}$ seems to be a good replacement for $\mathrm{Mg}^{2+}$ only if innersphere coordination to an N7 position (together with possible macrochelate formation) can take place. Again, this corresponds nicely to the results found with mono- and dinucleotides (Section 3) where for $\mathrm{Cd}^{2+}$ a high degree of macrochelate formation is found, although one would not have dared to predict that this might be a requirement for $\mathrm{Cd}^{2+}$ binding in nucleic acids.

\subsection{Metal ion binding to the Dickerson-Drew DNA dodecamer}

In the above sections we have seen that RNA can adopt highly complex structures, as e.g. in the ribosome where a large number of the nucleotides are not involved in common WatsonCrick base pairing, but instead in "mismatches", loops, and bulges. As a consequence, complicated three-dimensional architectures are formed with a multitude of (mostly) partly dehydrated $\mathrm{Mg}^{2+}$ ions bound within. Evaluation of the $\mathrm{Mg}^{2+}$ binding sites within the subtypeA HIV-1 DIS RNA duplex (Section 4.2) showed that partial dehydration of the first coordination sphere seems to occur mainly at unusual, i.e. non-helical, local structures when for example two phosphate-sugar backbones are in close neighborhood to each other. It will 
now be interesting to see, how divalent metal ions are bound to DNA, i.e. a nucleic acid, which adopts majorily a regular B-form duplex.

Certainly, the so-called Dickerson-Drew sequence is the structurally best investigated DNA sequence (Fig. 9). However, in terms of binding of divalent metal ions, to the best of our knowledge, there are only structures available in the presence of $\mathrm{Mg}^{2+}$ (PDB ID 436D) [160] and $\mathrm{Ca}^{2+}$ (PDB ID 463D) [161]. The high resolution structure by Egli and coworkers [160] reveals three fully occupied and two partially occupied $\mathrm{Mg}^{2+}$ sites. Four of the $\mathrm{Mg}^{2+}$ ions are in the hexahydrate and two in the pentahydrate form (Fig. 9). The coordination sites of these ions reveal no surprises and are well in-line with the above described findings with mono- and dinucleotides, as well as with the RNAs (Sections 3, 4.1 and 4.2): (i) Only one $\mathrm{Mg}^{2+}$ is located fully in the major groove whereas all others are found along the phosphatesugar backbone. These latter ions either bridge two phosphate groups of the same strand, of two strands within the duplex, or of strands of two different DNA duplexes in the crystal lattice. This clearly confirms the phosphate group as being the primary binding site. (ii) The $\mathrm{Mg}^{2+}$ located in the major groove is hexahydrated and coordinated solely to the guanine N7 and $\mathrm{O} 6$ atoms of two tandem GC base pairs, corresponding nicely to one of the hexahydrated $\mathrm{Mg}^{2+}$ ions in the ribosome structure (Fig. 7A and Section 4.1). (iii) The low extent of dehydration is well in line with the observations made at the HIV DIS structure described in Section 4.2, which revealed that dehydration occurs only at places where non-regular structures are present.

The four $\mathrm{Ca}^{2+}$ coordination sites coincide in no case with the ones identified for $\mathrm{Mg}^{2+}$, which confirms the results from the HIV DIS RNA evaluation described in Section 4.2. Two $\mathrm{Ca}^{2+}$ ions bind in the minor groove, both being heptahydrated and bound to several base functionalities of the DNA only by outersphere contacts. The two other $\mathrm{Ca}^{2+}$ ions are largely dehydrated and bind along the phosphate-sugar backbone thereby bridging two DNA duplexes in the crystal lattice. These findings confirm that $\mathrm{Ca}^{2+}$ indeed is a poor mimic of 
$\mathrm{Mg}^{2+}$

Taken together, these two structures of the Dickerson-Drew DNA sequence in presence of $\mathrm{Mg}^{2+}$ and $\mathrm{Ca}^{2+}$ reveal that in general DNA and RNA behave very similar in terms of their metal ion binding properties.

\section{Conclusions and outlook}

In this review we have brought together for the first time the extensive knowledge existing on metal ion binding of $\mathrm{Mg}^{2+}, \mathrm{Ca}^{2+}, \mathrm{Mn}^{2+}$, and $\mathrm{Cd}^{2+}$ to mono- and dinucleotides in solution with available results from solid state studies on large nucleic acid molecules, including the ribosome [19], a HIV dimerization initiation site [159], and the Dickerson-Drew DNA $[160,161]$

It is amazing to observe how much of the information regarding structures and binding sites can be transferred from the results obtained with low-molecular-weight ligands to the high-molecular-weight nucleic acids. This is very encouraging for the future in a threefold sense: Firstly, one may expect that the observations described herein are also valid for other metal ions, e.g. $\mathrm{Zn}^{2+}$. Secondly, the summarized information should help to plan in the future experiments involving metal ions in a more sophisticated way than in the past. Thirdly, one may use the knowledge summarized in this review to make predictions, based on the known coordination chemistry of nucleotides, towards the metal ion-binding properties of RNAs and DNAs in general.

\section{Abbreviations and definitions}

$\mathrm{ADP}^{3-} \quad$ adenosine 5'-diphosphate

A-form helix regular RNA duplex with the ribose in its 2'-endo (S) configuration

$\mathrm{AMP}^{2-} \quad$ adenosine 5'-monophosphate

$\mathrm{ATP}^{4-} \quad$ adenosine 5'-triphosphate 


\begin{tabular}{|c|c|}
\hline $\mathrm{CN}$ & coordination number \\
\hline cyt & cytosine \\
\hline $\mathrm{d}$ & 2'-deoxy \\
\hline $\mathrm{d}(\mathrm{GpG})^{-}$ & $2^{\prime}$-deoxyguanylyl $\left(3^{\prime} \rightarrow 5^{\prime}\right)-2^{\prime}$-deoxyguanosine \\
\hline $\mathrm{d}(\mathrm{pGpG})^{3-}$ & 2'-deoxyguanylyl $\left(5^{\prime} \rightarrow 3\right.$ ')-2'-deoxy-5'-guanylate \\
\hline $\mathrm{dGMP}^{2-}$ & 2'-deoxyguanosine 5'-monophosphate \\
\hline $\mathrm{dNTP}^{4-}$ & 2'-deoxynucleoside 5'-triphosphate \\
\hline $\mathrm{GDP}^{3-}$ & guanosine 5'-diphosphate \\
\hline $\mathrm{GMP}^{2-}$ & guanosine 5'-monophosphate \\
\hline $\mathrm{GTP}^{4-}$ & guanosine 5'-triphosphate \\
\hline gua & guanine \\
\hline$I$ & ionic strength \\
\hline$K_{\mathrm{a}}$ & acidity constant \\
\hline $\mathrm{NDP}^{3-}$ & nucleoside 5'-diphosphate \\
\hline $\mathrm{NMP}^{2-}$ & nucleoside 5'-monophosphate \\
\hline $\mathrm{NTP}^{4-}$ & nucleoside 5'-triphosphate \\
\hline $\mathrm{NXP}^{\mathrm{y}-}$ & $\begin{array}{l}\text { denotes the mono-, di-, or triphosphate form of any } \mathrm{NMP}^{2-}, \mathrm{NDP}^{3-} \text {, or } \\
\mathrm{NTP}^{4-}\end{array}$ \\
\hline pUpU ${ }^{3-}$ & uridylyl $\left(5^{\prime} \rightarrow 3^{\prime}\right)-5^{\prime}$-uridylate \\
\hline thy & thymine \\
\hline ura & uracil \\
\hline
\end{tabular}

\section{Acknowledgements}

The support of our studies by the University of Zürich and the Swiss National Science Foundation is gratefully acknowledged: SNF grant $21-105269 / 1$ to E.F. and SNFFörderungsprofessur to R.K.O.S., PP002-68733/1. 


\section{Figure Legends}

Fig. 1. Chemical structure of the five most common nucleobases in RNA and DNA. The structure of $\mathrm{ATP}^{4-}$ (with the adenine residue) is shown at the top together with its labeling scheme, 2'-deoxyguanosine (with the guanine moiety) is depicted in the middle together with the bridging phosphate groups as they occur in DNA, and the three pyrimidine nucleobases cytosine, uracil (in RNA) and thymine (instead of uracil in DNA) are drawn at the bottom. The major metal ion-coordinating atoms are shown in bold.

Fig. 2. Plots of the logarithms of the stability constants for the complexes of alkaline earth and divalent 3d-transition metal ions as well as $\mathrm{Zn}^{2+}$ and $\mathrm{Cd}^{2+}$ formed with the monophosphate $\left(\log K_{\mathrm{M}(\mathrm{AMP})_{\mathrm{op}}}^{\mathrm{M}}, \boldsymbol{\square}\right)$ or triphosphate residue $\left(\log K_{\mathrm{M}(\mathrm{ATP})_{\mathrm{op}}}^{\mathrm{M}}, \bullet\right)$ and with $\mathrm{ATP}^{4-}$ $\left(\log K_{\mathrm{M}(\mathrm{ATP})}^{\mathrm{M}}\right.$, o) $[116,118,122,162]$. The stabilities of the complexes including the four metal ions mainly discussed here, i.e. $\mathrm{Mg}^{2+}, \mathrm{Ca}^{2+}, \mathrm{Mn}^{2+}$, and $\mathrm{Cd}^{2+}$, are indicated by arrows. The increase in stability from left-to-right is in accord with the Irving-Williams series (which is not strictly followed for phosph(on)ate ligands) [156] and the Stability Ruler proposed by Martin [123-125].

Fig. 3. Inner- and outersphere coordination of $\mathrm{Cd}^{2+}$ in the $\mathrm{Cd}(\mathrm{GMP})\left(\mathrm{H}_{2} \mathrm{O}\right)_{5} \cdot 3 \mathrm{H}_{2} \mathrm{O}$ complex. The $\mathrm{Cd}^{2+}$ ion is directly coordinated to $\mathrm{N} 7$ of the guanine residue and additionally forms three hydrogen bonds via three coordinated water molecules to the phosphate group and the carbonyl oxygen O6. The $\mathrm{Cd}^{2+}$ ion is shown as a black sphere, the coordinated water molecules as grey spheres, and the nucleotide in lighter grey. The three hydrogen bonds are indicated by dotted lines. Three further water molecules present in the crystal structure are omitted for clarity. This figure has been prepared with MOLMOL [163] based on the 
coordinate file AGOPCD [127].

Fig. 4. X-ray structures of $\mathrm{M}^{2+}$ complexes with mononucleotides. A) Crystal structure of $\mathrm{CMP}^{2-}$ with $\mathrm{Cd}^{2+}$. The metal ion is coordinated to $\mathrm{N} 3$ of a cytosine residue, one water molecule, and four phosphate-oxygen atoms of three other $\mathrm{CMP}^{2-}$ molecules leading to a polymeric structure. B) A fully dehydrated $\mathrm{Mg}^{2+}$ ion bridges the triphosphate chains of two $\mathrm{ATP}^{4-}$ molecules thereby coordinating to every phosphate group. A second $\mathrm{Mg}^{2+}$ is present in its hexahydrate form. The octahedral coordination spheres of $\mathrm{Cd}^{2+}$ and $\mathrm{Mg}^{2+}$ bound to the nucleotides are indicated by dashed lines. Additional water molecules and the bis(2-pyridyl)amine ligand present (in B) are omitted for clarity. This figure has been prepared with MOLMOL [163] based on the coordinate files ACMPCD $\left(\mathrm{Cd}^{2+} / \mathrm{CMP}^{2-}\right)$ [132] and DECDIY $\left(\mathrm{Mg}^{2+} / \mathrm{ATP}^{4-}\right)[144]$.

Fig. 5. Chemical structure of the two dinucleotides discussed in this review, i.e. $\mathrm{pUpU}^{3-}$ (top) and $\mathrm{d}(\mathrm{pGpG})^{3-}$ (bottom), together with their numbering scheme.

Fig. 6. Innersphere versus outersphere binding of $\mathrm{Mg}^{2+}$ (or other metal ions) as it occurs (with mononucleotides or) within larger nucleic acid structures. A) Binding of $\mathrm{Mg}^{2+}$ to one N7 and one carbonyl O6 oxygen of two guanosine residues via innersphere coordination, as well as via a water molecule to a non-bridging phosphate oxygen. The three remaining sites of the hexacoordinated $\mathrm{Mg}^{2+}$ are occupied by water molecules (adapted from ref. [164]). B) A hexahydrated $\mathrm{Mg}^{2+}$ ion is solely bound via water molecules in an outersphere manner to RNA. This figure was adapted from a crystal structure of the P4-P5-P6 domains of the Tetrahymena group I intron (PDB 1GID) [5,165].

Fig. 7. $\mathrm{Mg}^{2+}$ binding in the large ribosomal subunit of $H$. marismortui [19]. A) A fully 
hexahydrated $\mathrm{Mg}^{2+}$ ion $\left(\mathrm{N}^{\circ} 38\right.$, according to the numbering scheme used in ref. [19]) is located in the major groove and makes solely outersphere contacts to nucleobase functional groups. B) Two $\mathrm{Mg}^{2+}$ ions showing either one $\left(\mathrm{N}^{\circ} 21\right.$, in the front) or two $\left(\mathrm{N}^{\circ} 34\right.$, in the back) innersphere contacts to non-bridging phosphate-oxygen atoms within a RNA loop structure. In addition, both ions show an extensive network of outersphere contacts, i.e. hydrogen bonds to purine N7 and O6 positions. C) Shown are two innersphere contacts of a $\mathrm{Mg}^{2+}\left(\mathrm{N}^{\circ} 11\right)$ in a cis-fashion to two guanine N7 positions of two different strands. D) An extensively dehydrated $\mathrm{Mg}^{2+}$ ion $\left(\mathrm{N}^{\circ} 8\right)$ bridges two nearby positioned sugar-phosphate backbones via innersphere coordination to three non-bridging phosphate-oxygens. Additional water molecules and further $\mathrm{Mg}^{2+}$ and $\mathrm{K}^{+}$ions coordinated in the vicinity are omitted for clarity. This figure has been prepared with MOLMOL [163] based on the PDB file 1S72 [19].

Fig. 8. Metal ion binding to the HIV dimerization initiation site (DIS). A) The palindromic sequence of the HIV DIS is shown on the left together with its crystal structure at the right, one strand being colored in red and the second one in green. The coordination sites of the $\mathrm{Mg}^{2+}$ ions (yellow spheres) are indicated by Greek letters. The water molecules have been omitted for clarity. B) Overlay of the structures of the $\mathrm{Mg}^{2+}$ bound (red and dark green) and $\mathrm{Mn}^{2+}$ bound (orange and light green) forms. The $\mathrm{Mg}^{2+}$ ions are shown as yellow and the $\mathrm{Mn}^{2+}$ ions as blue spheres. The water molecules have been omitted for clarity. C) Close-up view of the $\delta$-coordination site of $\mathrm{Mg}^{2+}$ with two innersphere contacts to two non-bridging phosphateoxygen atoms of A8 and G9 of opposite strands bringing the two backbones close together. All water molecules not being coordinated to $\mathrm{Mg}^{2+}$ are omitted for clarity. D) Close-up view of the $\varepsilon$ and $\gamma^{\prime}$-binding sites of $\mathrm{Mg}^{2+}$. The $\varepsilon-\mathrm{Mg}^{2+}$ is partially dehydrated with two innersphere contacts to the $R_{\mathrm{p}}$-oxygen of $\mathrm{A} 8$ and N7 of G9. All water molecules not being coordinated to the $\mathrm{Mg}^{2+}$ ions are omitted for clarity. This figure has been prepared with MOLMOL [163] based on the PDB files 462D $\left(\mathrm{Mg}^{2+}\right)$ and 1 Y $90\left(\mathrm{Mn}^{2+}\right)$ [159]. 
Fig. 9. $\mathrm{Mg}^{2+}$ and $\mathrm{Ca}^{2+}$ binding to Dickerson-Drew DNA whose sequence is given at the left. The superposition of crystal structures of the $\mathrm{Mg}^{2+}$ bound DNA (in blue) and the $\mathrm{Ca}^{2+}$ bound form (in green) is shown. It can be clearly seen that the five localized $\mathrm{Mg}^{2+}$ ions (yellow spheres, one is on the backside of the duplex) and the four $\mathrm{Ca}^{2+}$ ions (magenta spheres) occupy different binding sites. Interestingly, the $\mathrm{Mg}^{2+}$ ions are in their hexahydrated form, whereas two of the $\mathrm{Ca}^{2+}$ ions undergo partial innersphere coordination to phosphate oxygens and a carbonyl oxygen. The phosphate and the guanine moiety in the top right corner belong to the neighboring DNA duplex, the rest of which has been omitted for clarity. This figure has been prepared with MOLMOL [163] based on the PDB files 436D $\left(\mathrm{Mg}^{2+}\right)$ [160] and 463D $\left(\mathrm{Ca}^{2+}\right)$ [161]. 


\section{Table 1}

Comparison of some physico-chemical properties of $\mathrm{Mg}^{2+}, \mathrm{Ca}^{2+}, \mathrm{Mn}^{2+}$, and $\mathrm{Cd}^{2+}$ in aqueous solution. Given are the ionic radii and the preferred coordination number $(\mathrm{CN})$ of the $\mathrm{M}^{2+}$ ions, the enthalpy of hydration $\left(\Delta \mathrm{H}_{\mathrm{Hydr}}\right)$, the distance between the metal ion and a coordinated water molecule, the acidity constant $\left(\mathrm{p} K_{\mathrm{M}\left(\mathrm{H}_{2} \mathrm{O}\right)_{6}}^{\mathrm{H}}\right)$ of a water molecule in the hexa-aqua complex, as well as the ligand exchange rate from the first coordination sphere of the metal ion $\left(k_{\mathrm{exch}}\right)$.

\begin{tabular}{lccccc}
\hline & $\mathrm{Mg}^{2+}$ & $\mathrm{Ca}^{2+}$ & $\mathrm{Mn}^{2+}$ & $\mathrm{Cd}^{2+}$ & ref. \\
\hline Ionic radius $(\AA)$ & 0.72 & $1.00(1.12)^{\mathrm{a}}$ & $0.83^{\mathrm{b}}$ & 0.95 & {$[166]$} \\
$\mathrm{CN}$ & 6 & $6(8)^{\mathrm{a}}$ & 6 & 6 & \\
Preferred ligands & $\mathrm{O}$ & $\mathrm{O}$ & $\mathrm{O} / \mathrm{N}$ & $\mathrm{N} / \mathrm{O}$ & \\
$\Delta \mathrm{H}_{\mathrm{Hydr}}\left(\mathrm{kJmol}^{-1}\right)$ & 1858 & $1570(1657)^{\mathrm{a}}$ & 1762 & 1640 & {$[167]$} \\
$\mathrm{M} \cdots \mathrm{OH}_{2}(\AA)$ & 2.04 & $2.37(2.48)^{\mathrm{a}}$ & 2.18 & 2.35 & {$[167]$} \\
$\mathrm{p} K_{\mathrm{M}\left(\mathrm{H}_{2} \mathrm{O}\right)_{6}}^{\mathrm{H}}\left(25^{\circ} \mathrm{C}\right)$ & $11.44 \pm 0.1$ & $12.85 \pm 0.1$ & 10.59 & 10.2 & {$[168]$} \\
$k_{\text {exch }}\left(\mathrm{s}^{-1}\right)$ & $6.7 \cdot 10^{5}$ & $\approx 10^{9}$ & $2.1 \cdot 10^{7}$ & $6.8 \cdot 10^{8}$ & {$[169-171]$} \\
\hline
\end{tabular}

a The numbers in brackets refer to $\mathrm{CN}=8$.

${ }^{\mathrm{b}}$ High-spin electron configuration. 


\section{Table 2}

Experimentally determined stability constants, $K_{\mathrm{M}(\mathrm{NXP})}^{\mathrm{M}}$, for $\mathrm{M}(\mathrm{NXP})^{(\mathrm{y}-2)-}$ complexes, i.e. including the contribution of macrochelate formation, and calculated stability constants, $K_{\mathrm{M}(\mathrm{NXP})_{\mathrm{op}}}^{\mathrm{M}}$, for the corresponding isomers with a sole phosphate coordination of $\mathrm{Mg}^{2+}$ and $\mathrm{Ca}^{2+} . \mathrm{The}^{2}$ extent of intramolecular macrochelate formation in the various $\mathrm{M}(\mathrm{NXP})^{(\mathrm{y}-2)-}$ complexes is given in columns 4 and 5 as well as 8 and 9 (see also text in Section 3.1). All data refer to aqueous solution at $25^{\circ} \mathrm{C}$ and $I=0.1 \mathrm{M}\left(\mathrm{NaNO}_{3}\right) .^{\mathrm{a}}$

\begin{tabular}{|c|c|c|c|c|c|c|c|c|c|}
\hline \multirow[b]{2}{*}{$\mathrm{NXP}^{\mathrm{y}-}$} & \multicolumn{4}{|c|}{$\mathrm{Mg}^{2+}$} & \multicolumn{5}{|c|}{$\mathrm{Ca}^{2+}$} \\
\hline & $\log K_{\mathrm{M}(\mathrm{NXP})}^{\mathrm{M}}$ & $\log K_{\mathrm{M}(\mathrm{NXP})_{\mathrm{op}}}^{\mathrm{M}}$ & $K_{\mathrm{I}}$ & $\% \mathrm{M}(\mathrm{NXP})_{\mathrm{cl}}^{(\mathrm{y}-2)-}$ & $\log K_{\mathrm{M}(\mathrm{NXP})}^{\mathrm{M}}$ & $\log K_{\mathrm{M}(\mathrm{NXP})_{\mathrm{op}}}^{\mathrm{M}}$ & $K_{\mathrm{I}}$ & $\% \mathrm{M}(\mathrm{NXP})_{\mathrm{cl}}^{(\mathrm{y}-2)-}$ & ref. \\
\hline $\mathrm{AMP}^{2-}$ & $1.62 \pm 0.04$ & $1.56 \pm 0.03$ & $0.15 \pm 0.13$ & $13 \pm 10$ & $1.48 \pm 0.03$ & $1.45 \pm 0.05$ & $0.07 \pm 0.14$ & $0(7 \pm 13)$ & {$[118,122]$} \\
\hline $\mathrm{ADP}^{3-}$ & $3.36 \pm 0.03$ & $3.30 \pm 0.03$ & $0.15 \pm 0.11$ & $13 \pm 9$ & $2.95 \pm 0.02$ & $2.91 \pm 0.03$ & $0.10 \pm 0.09$ & $9 \pm 8$ & [118] \\
\hline $\mathrm{ATP}^{4-}$ & $4.29 \pm 0.03$ & $4.21 \pm 0.04$ & $0.20 \pm 0.14$ & $17 \pm 10$ & $3.91 \pm 0.03$ & $3.84 \pm 0.05$ & $0.17 \pm 0.16$ & $2 \pm 6$ & {$[116,162]$} \\
\hline $\mathrm{GMP}^{2-}$ & $1.73 \pm 0.03$ & $1.57 \pm 0.03$ & $0.45 \pm 0.14$ & $31 \pm 7$ & $1.57 \pm 0.03$ & $1.45 \pm 0.05$ & $0.32 \pm 0.18$ & $24 \pm 10$ & {$[122]$} \\
\hline $\mathrm{GDP}^{3-}$ & $3.39 \pm 0.04$ & $3.29 \pm 0.03$ & $0.26 \pm 0.14$ & $21 \pm 9$ & $3.05 \pm 0.05$ & $2.90 \pm 0.03$ & $0.41 \pm 0.19$ & $29 \pm 19$ & {$[117,162]$} \\
\hline $\mathrm{GTP}^{4-}$ & $4.31 \pm 0.04$ & $4.21 \pm 0.04$ & $0.26 \pm 0.17$ & $21 \pm 11$ & $3.96 \pm 0.03$ & $3.84 \pm 0.05$ & $0.32 \pm 0.18$ & $24 \pm 10$ & [162] \\
\hline
\end{tabular}

a All error limits given are three times the standard error of the mean value or the sum of the probable systematic errors, whichever is larger. 


\section{Table 3}

Experimentally determined stability constants, $K_{\mathrm{M}(\mathrm{NXP})}^{\mathrm{M}}$, for $\mathrm{M}(\mathrm{NXP})^{(\mathrm{y}-2)-}$ complexes, i.e. including the contribution of macrochelate formation, and calculated stability constants, $K_{\mathrm{M}(\mathrm{NXP})_{\text {op }}}^{\mathrm{M}}$, for the corresponding isomers with a sole phosphate coordination of $\mathrm{Mn}^{2+}$ and $\mathrm{Cd}^{2+} . \mathrm{The}^{\mathrm{extent}}$ of intramolecular macrochelate formation in the various $\mathrm{M}(\mathrm{NXP})^{(\mathrm{y}-2)-}$ complexes is given in columns 4 and 5 as well as 8 and 9 (see also text in Section 3.1). All data refer to aqueous solution at $25^{\circ} \mathrm{C}$ and $I=0.1 \mathrm{M}\left(\mathrm{NaNO}_{3}\right){ }^{\mathrm{a}}$

\begin{tabular}{|c|c|c|c|c|c|c|c|c|c|}
\hline \multirow[b]{2}{*}{$\mathrm{NXP}^{\mathrm{y}-}$} & \multicolumn{4}{|c|}{$\mathrm{Mn}^{2+}$} & \multicolumn{5}{|c|}{$\mathrm{Cd}^{2+}$} \\
\hline & $\log K_{\mathrm{M}(\mathrm{NXP})}^{\mathrm{M}}$ & $\log K_{\mathrm{M}(\mathrm{NXP})_{\mathrm{op}}}^{\mathrm{M}}$ & $K_{\mathrm{I}}$ & $\% \mathrm{M}(\mathrm{NXP})_{\mathrm{cl}}^{(\mathrm{y}-2)-}$ & $\log K_{\mathrm{M}(\mathrm{NXP})}^{\mathrm{M}}$ & $\log K_{\mathrm{M}(\mathrm{NXP})_{o p}}^{\mathrm{M}}$ & $K_{\mathrm{I}}$ & $\% \mathrm{M}(\mathrm{NXP})_{\mathrm{cl}}^{(\mathrm{y}-2)-}$ & ref. \\
\hline $\mathrm{AMP}^{2-}$ & $2.23 \pm 0.02$ & $2.16 \pm 0.05$ & $0.17 \pm 0.15$ & $15 \pm 11$ & $2.74 \pm 0.05$ & $2.44 \pm 0.05$ & $1.00 \pm 0.32$ & $50 \pm 8$ & {$[118,122]$} \\
\hline $\mathrm{ADP}^{3-}$ & $4.22 \pm 0.02$ & $4.12 \pm 0.03$ & $0.26 \pm 0.10$ & $21 \pm 7$ & $4.63 \pm 0.04$ & $4.27 \pm 0.03$ & $1.29 \pm 0.26$ & $56 \pm 5$ & [118] \\
\hline $\mathrm{ATP}^{4-}$ & $5.01 \pm 0.08$ & $4.93 \pm 0.03$ & $0.20 \pm 0.22$ & $17 \pm 15$ & $5.34 \pm 0.03$ & $5.07 \pm 0.03$ & $0.86 \pm 0.17$ & $46 \pm 5$ & {$[116,162]$} \\
\hline $\mathrm{GMP}^{2-}$ & $2.42 \pm 0.05$ & $2.17 \pm 0.05$ & $0.78 \pm 0.29$ & $44 \pm 9$ & $3.25 \pm 0.03$ & $2.46 \pm 0.05$ & $5.17 \pm 0.83$ & $84 \pm 2$ & [122] \\
\hline $\mathrm{GDP}^{3-}$ & $4.35 \pm 0.06$ & $4.11 \pm 0.03$ & $0.74 \pm 0.27$ & $42 \pm 9$ & $4.86 \pm 0.03$ & $4.25 \pm 0.03$ & $3.07 \pm 0.40$ & $75 \pm 2$ & {$[117,162]$} \\
\hline $\mathrm{GTP}^{4-}$ & $5.36 \pm 0.03$ & $4.93 \pm 0.03$ & $1.69 \pm 0.25$ & $63 \pm 3$ & $5.82 \pm 0.05$ & $5.07 \pm 0.03$ & $4.62 \pm 0.78$ & $82 \pm 2$ & {$[162]$} \\
\hline
\end{tabular}

a All error limits given are three times the standard error of the mean value or the sum of the probable systematic errors, whichever is larger. 


\section{Table 4}

Comparison of the stability enhancements observed for several $\mathrm{M}^{2+}$ complexes of $\mathrm{d}(\mathrm{pGpG})^{3-}$, $\mathrm{dGMP}^{2-}$, and $\mathrm{GMP}^{2-}$ due to the interactions of the phosphate-coordinated metal ions with the guanine residues. All data refer to aqueous solution at $25^{\circ} \mathrm{C}$ and $I=0.1 \mathrm{M}\left(\mathrm{NaNO}_{3}\right){ }^{\mathrm{a}}$

\begin{tabular}{lcccc}
\hline & $\log \Delta_{\mathrm{M} / \mathrm{d}(\mathrm{pGpG}) / \mathrm{dGMP} / \mathrm{cor}}^{*}$ & $\log \Delta_{\mathrm{M} / \mathrm{dGMP}}$ & $\log \Delta_{\mathrm{M} / \mathrm{GMP}}$ & $\Delta \log \Delta_{\mathrm{M} / \mathrm{d}(\mathrm{pGpG} / \mathrm{dGMP}}^{*}$ \\
\hline $\mathrm{Mg}^{2+}$ & $0.55 \pm 0.08$ & $0.23 \pm 0.05$ & $0.16 \pm 0.04$ & $0.32 \pm 0.09^{\mathrm{d}}$ \\
$\mathrm{Zn}^{2+}$ & $1.16 \pm 0.09^{\mathrm{b}}$ & $0.84 \pm 0.08$ & $0.69 \pm 0.07$ & $0.32 \pm 0.12^{\mathrm{d}}$ \\
$\mathrm{Cd}^{2+}$ & $1.21 \pm 0.09$ & $0.92 \pm 0.11^{\mathrm{c}}$ & $0.79 \pm 0.06$ & $0.29 \pm 0.14^{\mathrm{d}}$ \\
$\mathrm{Cu}^{2+}$ & & $1.14 \pm 0.07$ & $0.97 \pm 0.07$ & \\
\hline
\end{tabular}

${ }^{a}$ For the error limits see footnote 'a' in Tables 2 or 3 . The results listed in columns 2 (chargecorrected stability enhancements due to $\mathrm{M}[\mathrm{d}(\mathrm{pGpG})]_{\mathrm{cl} / \mathrm{N} 7}^{-}$formation), 3 (due to $\left.\mathrm{M}(\mathrm{dGMP})_{\mathrm{cl}}\right)$, and 4 (due to $\left.\mathrm{M}(\mathrm{GMP})_{\mathrm{cl}}\right)$ are from refs. [122,149] and [150], respectively.

${ }^{b}$ This value is corrected for the extent of the interaction with the neighboring phosphate group, i.e. from $K_{\mathrm{I} / \mathrm{N} 7}=13.44 \pm 3.08$ follows the above value [149].

c This value is an estimate based on the following reasonings: The differences $\Delta \log \Delta_{\mathrm{M} / \mathrm{d}(\mathrm{pGpG}) / \mathrm{dGMP}}=\log \Delta_{\mathrm{M} / \mathrm{dGMP}}-\log \Delta_{\mathrm{M} / \mathrm{GMP}}$ are for $\mathrm{Mg}^{2+} 0.07 \pm 0.06[=(0.23 \pm 0.05)-$ $(0.16 \pm 0.04)]$, for $\mathrm{Zn}^{2+} 0.15 \pm 0.11[=(0.84 \pm 0.08)-(0.69 \pm 0.07)]$, and for $\mathrm{Cu}^{2+} 0.17 \pm 0.10$ $[=(1.14 \pm 0.07)-(0.97 \pm 0.07)]$. The corresponding average equals $\Delta \log \Delta=0.13 \pm 0.09$. Hence, one may transform $\log \Delta_{\mathrm{Cd} / \mathrm{GMP}}=0.79 \pm 0.06$ into $\log \Delta_{\mathrm{Cd} / \mathrm{dGMP}}=(0.79 \pm 0.06)+(0.13$ $\pm 0.09)=0.92 \pm 0.11$ as given above

${ }^{\mathrm{d}}$ The three values in column five give on average $\Delta \log \Delta_{\mathrm{M} / \mathrm{d}(\mathrm{pGpG}) / \mathrm{dGMP} / \mathrm{av}}^{*}=0.31 \pm 0.07$. If one totally attributes this extra stability enhancement observed for the $\mathrm{M}[\mathrm{d}(\mathrm{pGpG})]^{-}$ complexes, compared to the situation in $\mathrm{M}(\mathrm{dGMP})$, to a preformed favorable orientation of the $\mathrm{d}(\mathrm{pGpG})^{3-}$ ligand, one may estimate [156] the extent of intramolecular stacking between the purine residues in $\mathrm{d}(\mathrm{pGpG})^{3-}$ and obtains for the intramolecular constant $K_{\mathrm{I} / \mathrm{stack}}=10^{\Delta \log \Delta^{*}}$ $-1=1.04$ and for the percentage of the stacked species, $\%[\mathrm{~d}(\mathrm{pGpG})]_{\text {stack }}^{3-}=51 \%$. See also the discussion in the text of Section 3.3. 


\section{References}

[1] R.F. Gesteland, T.R. Cech, J.F. Atkins (Eds.), The RNA World, 3rd ed., Cold Spring Harbor Press, 2006.

[2] N. Ban, P. Nissen, J. Hansen, P.B. Moore, T.A. Steitz, Science 289 (2000) 902-920.

[3] F. Schlünzen, A. Tocilj, R. Zarivach, J. Harms, M. Gluehmann, D. Janell, A. Bashan, H. Bartels, I. Agmon, F. Franceschi, A. Yonath, Cell 102 (2000) 615-623.

[4] B.T. Wimberly, D.E. Brodersen, W.M. Clemons, Jr., R.J. Morgan-Warren, A.P. Carter, C. Vonrhein, T. Hartsch, V. Ramakrishnan, Nature 407 (2000) 327-339.

[5] J.H. Cate, R.L. Hanna, J.A. Doudna, Nat. Struct. Biol. 4 (1997) 553-558.

[6] C.C. Correll, B. Freeborn, P.B. Moore, J.A. Steitz, Cell 91 (1997) 705-712.

[7] R.K.O. Sigel, A.M. Pyle, Chem. Rev. (2007) available online, DOI: $10.1021 / \mathrm{cr} 0502605$.

[8] R.K.O. Sigel, Eur. J. Inorg. Chem. 12 (2005) 2281-2292.

[9] R. Shiman, D.E. Draper, J. Mol. Biol. 302 (2000) 79-91.

[10] G.S. Manning, Biophys. Chem. 7 (1977) 141-145.

[11] D.E. Draper, D. Grilley, A.M. Soto, Annu. Rev. Biophys. Biomol. Struct. 34 (2005) 221-243.

[12] V.K. Misra, D.E. Draper, J. Mol. Biol. 317 (2002) 507-521.

[13] V.K. Misra, D.E. Draper, Proc. Natl. Acad. Sci. USA 98 (2001) 12456-12461.

[14] V.K. Misra, D.E. Draper, Biopolymers 48 (1998) 113-135.

[15] G.S. Manning, Quart. Rev. Biophys. 11 (1978) 179-246.

[16] G.S. Manning, Biopolymers 69 (2003) 137-143.

[17] C.F. Anderson, M.T. Record, Jr., Annu. Rev. Biophys. Biophys. Chem. 19 (1990) 423-465.

[18] C.F. Anderson, M.T. Record, Jr., Biophys. Chem. 11 (1980) 353-360.

[19] D.J. Klein, P.B. Moore, T.A. Steitz, RNA 10 (2004) 1366-1379.

[20] S. Dorner, A. Barta, Biol. Chem. 380 (1999) 243-251.

[21] R.K.O. Sigel, A. Vaidya, A.M. Pyle, Nat. Struct. Biol. 7 (2000) 1111-1116. 
[22] C. Berens, B. Streicher, R. Schroeder, W. Hillen, Chem. Biol. 5 (1998) 163-175.

[23] A.M. Pyle, Met. Ions Biol. Syst. 32 (1996) 479-519.

[24] V.J. DeRose, Curr. Op. Struct. Biol. 13 (2003) 317-324.

[25] A.M. Pyle, J. Biol. Inorg. Chem. 7 (2002) 679-690.

[26] M.J. Fedor, Curr. Op. Struct. Biol. 12 (2002) 289-295.

[27] L.D. Williams, Top. Curr. Chem. 253 (2005) 77-88.

[28] R.K.O. Sigel, A.M. Pyle, Met. Ions Biol. Syst. 40 (2003) 477-512.

[29] B. Knobloch, M.C. Erat, R.K.O. Sigel, manuscript in preparation.

[30] M.C. Erat, O. Zerbe, T. Fox, R.K.O. Sigel, ChemBioChem (2007) available online, DOI: $10.1002 /$ cbic.200600459.

[31] M.C. Erat, R.K.O. Sigel, submitted for publication.

[32] B. Knobloch, R.K.O. Sigel, Chimia 60 (2006) 408.

[33] R.L. Gonzalez, Jr., I. Tinoco Jr., J. Mol. Biol. 289 (1999) 1267-1282.

[34] T.C. Gluick, R.B. Gerstner, D.E. Draper, J. Mol. Biol. 270 (1997) 451-463.

[35] J.H. Davis, M. Tonelli, L.G. Scott, L. Jaeger, J.R. Williamson, S.E. Butcher, J. Mol. Biol. 351 (2005) 371-382.

[36] R.K.O. Sigel, D.G. Sashital, D.L. Abramovitz, A.G. Palmer III, S.E. Butcher, A.M. Pyle, Nat. Struct. Mol. Biol. 11 (2004) 187-192.

[37] A. Vaidya, H. Suga, Biochemistry 40 (2001) 7200-7210.

[38] M. Hertweck, M.W. Müller, Eur. J. Biochem. 268 (2001) 4610-4620.

[39] S.R. Morrissey, T.E. Horton, V.J. DeRose, J. Am. Chem. Soc. 122 (2000) 3473-3481.

[40] T.E. Horton, D.R. Clardy, V.J. DeRose, Biochemistry 37 (1998) 18094-18101.

[41] Y. Tanaka, K. Taira, Rec. Res. Dev. Org. Chem. 9 (2005) 93-118.

[42] Y. Tanaka, K. Taira, Chem. Commun. (2005) 2069-2079.

[43] B. Knobloch, R.K.O. Sigel, results to be published.

[44] I. Bertini, A. Sigel, H. Sigel (Eds.), Handbook on Metalloproteins, Marcel Dekker Inc., New York, 2001.

[45] E.M. Osborne, J.E. Schaak, V.J. DeRose, RNA 11 (2005) 187-196. 
[46] M. Roychowdhury-Saha, D.H. Burke, RNA 12 (2006) 1846-1852.

[47] A.S. Burton, N. Lehman, Biochimie 88 (2006) 819-825.

[48] M.C. Erat, O. Fedorova, R.K.O. Sigel, manuscript in preparation.

[49] A.K. Brown, J. Li, C.M.B. Pavot, Y. Lu, Biochemistry 42 (2003) 7152-7161.

[50] Y. Lu, J. Liu, J. Li, P.J. Bruesehoff, C.M.B. Pavot, A.K. Brown, Biosensors \& Bioelectronics 18 (2003) 529-540.

[51] Y. Lu, Chem. Eur. J. 8 (2002) 4588-4596.

[52] M.C. Erat, M. Wächter, R.K.O. Sigel, CHIMIA 58 (2004) 479.

[53] M.J. Berridge, Biochim. Biophys. Acta 1742 (2004) 3-7.

[54] G. Ermak, K.J.A. Davies, Mol. Immunol. 38 (2001) 713-721.

[55] T. Pozzan, R. Rizzuto, Nat. Cell Biol. 2 (2000) E25-E27.

[56] R.G. Hansford, D. Zorov, Mol. Cell. Biochem. 184 (1998) 359-369.

[57] E. Carafoli, Nature Rev. Mol. Cell Biol. 4 (2003) 326-332.

[58] E. Carafoli, Trends Biochem. Sci. 28 (2003) 175-181.

[59] R.L. Gonzalez, Jr., I. Tinoco, Jr., Methods Enzymol. 338 (2001) 421-443.

[60] P.M. Gordon, J.A. Piccirilli, Nat. Struct. Biol. 8 (2001) 893-898.

[61] S.-O. Shan, A.V. Kravchuk, J.A. Piccirilli, D. Herschlag, Biochemistry 40 (2001) $5161-5171$

[62] M.P. Latham, D.J. Brown, S.A. McCallum, A. Pardi, ChemBioChem 6 (2005) 14921505.

[63] K.F. Blount, O.C. Uhlenbeck, Ann. Rev. Biophys. Biomol. Struct. 34 (2005) 415-440.

[64] J. Hsieh, C.A. Fierke, Encycl. Biol. Chem. 3 (2004) 733-737.

[65] C. Hammann, D.M.J. Lilley, ChemBioChem 3 (2002) 690-700.

[66] S.E. Butcher, Curr. Op. Struct. Biol. 11 (2001) 315-320.

[67] J.B. Murray, A.A. Seyhan, N.G. Walter, J.M. Burke, W.G. Scott, Chem. Biol. 5 (1998) 587-595.

[68] J.L. O'Rear, S. Wang, A.L. Feig, L. Beigelman, O.C. Uhlenbeck, D. Herschlag, RNA 7 (2001) 537-545. 
[69] M. Martick, W.G. Scott, Cell 126 (2006) 309-320.

[70] A.L. Feig, W.G. Scott, O.C. Uhlenbeck, Science 279 (1998) 81-84.

[71] J.B. Murray, D.P. Terwey, L. Maloney, A. Karpeisky, N. Usman, L. Beigelman, W.G. Scott, Cell 92 (1998) 665-673.

[72] S. Wang, K. Karbstein, A. Peracchi, L. Beigelman, D. Herschlag, Biochemistry 38 (1999) 14363-14378.

[73] M. Maderia, L.M. Hunsicker, V.J. DeRose, Biochemistry 39 (2000) 12113-12120.

[74] M.D. Canny, F.M. Jucker, E. Kellogg, A. Khvorova, S.D. Jayasena, A. Pardi, J. Am. Chem. Soc. 126 (2004) 10848-10849.

[75] M. De la Pena, S. Gago, R. Flores, EMBO J. 22 (2003) 5561-5570.

[76] A. Khvorova, A. Lescoute, E. Westhof, S.D. Jayasena, Nature Struct. Biol. 10 (2003) 708-712.

[77] K. Lehmann, U. Schmidt, Critical Rev. Biochem. Mol. Biol. 38 (2003) 249-303.

[78] A.M. Pyle, Science 261 (1993) 709-714.

[79] P.Z. Qin, A.M. Pyle, Biochemistry 36 (1997) 4718-4730.

[80] L.J. Su, C. Waldsich, A.M. Pyle, Nucleic Acids Res. 33 (2005) 6674-6687.

[81] P.M. Gordon, E.J. Sontheimer, J.A. Piccirilli, RNA 6 (2000) 199-205.

[82] P.M. Gordon, E.J. Sontheimer, J.A. Piccirilli, Biochemistry 39 (2000) 12939-12952.

[83] E.J. Sontheimer, P.M. Gordon, J.A. Piccirilli, Genes Dev. 13 (1999) 1729-1741.

[84] M. Boudvillain, A.M. Pyle, EMBO J. 17 (1998) 7091-7104.

[85] M. Boudvillain, A. de Lencastre, A.M. Pyle, Nature 406 (2000) 315-318.

[86] N. Lehman, G.F. Joyce, Curr. Biol. 3 (1993) 723-734.

[87] N. Lehman, G.F. Joyce, Nature 361 (1993) 182-185.

[88] P.L. Adams, M.R. Stahley, A.B. Kosek, J. Wang, S.A. Strobel, Nature 430 (2004) 4550

[89] M.R. Stahley, S.A. Strobel, Science 309 (2005) 1587-1590.

[90] J. Li, W.C. Zheng, A.H. Kwon, Y. Lu, Nucleic Acids Res. 28 (2000) 481-488.

[91] S.W. Santoro, G.F. Joyce, Proc. Natl. Acad. Sci. USA 94 (1997) 4262-4266. 
[92] D. Faulhammer, M. Famulok, Angew. Chem., Int. Ed. 35 (1996) 2837-2841.

[93] D. Faulhammer, M. Famulok, J. Mol. Biol. 269 (1997) 188-202.

[94] A. Peracchi, J. Biol. Chem. 275 (2000) 11693-11697.

[95] S.W. Santoro, G.F. Joyce, Biochemistry 37 (1998) 13330-13342.

[96] J. Li, Y. Lu, J. Am. Chem. Soc. 122 (2000) 10466-10467.

[97] J.W. Liu, Y. Lu, Chem. Mater. 16 (2004) 3231-3238.

[98] J.W. Liu, Y. Lu, J. Fluoresc. 14 (2004) 343-354.

[99] J.W. Liu, Y. Lu, Anal. Chem. 75 (2003) 6666-6672.

[100] Y. Lu, J.W. Liu, J. Li, P.J. Bruesehoff, C.M.B. Pavot, A.K. Brown, Biosens. Bioelectron. 18 (2003) 529-540.

[101] H.C. Losey, A.J. Ruthenburg, G.L. Verdine, Nature Struct. Mol. Biol. 13 (2006) 153159.

[102] G.C. Ireton, M.E. Black, B.L. Stoddard, Structure 11 (2003) 961-972.

[103] M. Kolberg, K.R. Strand, P. Graff, K.K. Andersson, Biochim. Biophys. Acta 1699 (2004) 1-34.

[104] H. Sigel, R. Griesser, Chem. Soc. Rev. 34 (2005) 875-900.

[105] H. Sigel, Coord. Chem. Rev. 100 (1990) 453-539.

[106] T.A. Steitz, J.A. Steitz, Proc. Natl. Acad. Sci. USA 90 (1993) 6498-6502.

[107] E. Freisinger, A.P. Grollman, H. Miller, C. Kisker, EMBO J. 23 (2004) 1494-1505.

[108] Y.W. Yin, T.A. Steitz, Cell 116 (2004) 393-404.

[109] T.A. Steitz, Curr. Op. Struct. Biol. 14 (2004) 4-9.

[110] L.W. Tari, A. Matte, H. Goldie, L.T.J. Delbaere, Nat. Struct. Biol. 4 (1997) 990-994.

[111] I. Sagi, Y. Hochman, G. Bunker, S. Carmeli, C. Carmeli, J. Synchr. Rad. 6 (1999) 409-410.

[112] H. Sigel, Inorg. Chim. Acta 198-200 (1992) 1-11.

[113] H. Sigel, Eur. J. Biochem. 165 (1987) 65-72.

[114] H. Sigel, E.M. Bianchi, N.A. Corfu, Y. Kinjo, R. Tribolet, R.B. Martin, J. Chem. Soc., Perkin Trans. 2 (2001) 507-511. 
[115] H. Sigel, Pure Appl. Chem. 76 (2004) 375-388.

[116] H. Sigel, R. Tribolet, R. Malini-Balakrishnan, R.B. Martin, Inorg. Chem. 26 (1987) 2149-2157.

[117] R.K.O. Sigel, H. Sigel, Met. Ions Life Sci. 2 (2007) 109-180.

[118] E.M. Bianchi, S.A.A. Sajadi, B. Song, H. Sigel, Chem. Eur. J. 9 (2003) 881-892.

[119] H. Sigel, S.S. Massoud, R. Tribolet, J. Am. Chem. Soc. 110 (1988) 6857-6865.

[120] R.K.O. Sigel, B. Song, H. Sigel, J. Am. Chem. Soc. 119 (1997) 744-755.

[121] R.B. Martin, H. Sigel, Comments Inorg. Chem. 6 (1988) 285-314.

[122] H. Sigel, B. Song, Met. Ions Biol. Syst. 32 (1996) 135-206.

[123] R.B. Martin, Met. Ions Biol. Syst. 20 (1986) 21-65.

[124] R.B. Martin, in: R.B. King (Ed.), Encyclopedia of Inorganic Chemistry Vol. 4, pp. 2185-2196, Wiley, Chichester, 1994.

[125] R.B. Martin, in: R.A. Meyers (Ed.), Encyclopedia of Molecular Biology and Molecular Medicine Vol. 1, pp. 125-134, VCH, Weinheim, 1996.

[126] H. Sigel, S.S. Massoud, N.A. Corfù, J. Am. Chem. Soc. 116 (1994) 2958-2971.

[127] K. Aoki, Acta Crystallogr. B 32 (1976) 1454-1459.

[128] L.E. Kapinos, A. Holý, J. Günter, H. Sigel, Inorg. Chem. 40 (2001) 2500-2508.

[129] G. Kampf, L.E. Kapinos, R. Griesser, B. Lippert, H. Sigel, J. Chem. Soc. Perkin Trans. 2 (2002) 1320-1327.

[130] K. Aoki, Met. Ions Biol. Syst. 32 (1996) 91-134.

[131] K. Aoki, in: M. Vaghefi (Ed.), Nucleoside Triphosphates and Their Analogs, pp. 115132, Taylor \& Francis, Boca Raton, USA, 2005.

[132] J.K. Shiba, R. Bau, Inorg. Chem. 17 (1978) 3484-3488.

[133] K. Aoki, W. Saenger, J. Inorg. Biochem 20 (1984) 225-245.

[134] G.R. Clark, J.D. Orbell, Acta Crystallogr. B 34 (1978) 1815-1822.

[135] K. Aoki, J. Chem. Soc., Chem. Commun. (1979) 589-591.

[136] K. Aoki, W. Saenger, J. Chem. Soc., Dalton Trans. (1984) 1401-1409.

[137] K. Trueblood, P. Horn, V. Luzzati, Acta Crystallogr. 14 (1961) 965-\&. 
[138] T. Sato, Acta Crystallogr. C 40 (1984) 736-738.

[139] B. Knobloch, W. Linert, H. Sigel, Proc. Natl. Acad. Sci. USA 102 (2005) 7459-7464.

[140] B. Knobloch, H. Sigel, J. Biol. Inorg. Chem. 9 (2004) 365-373.

[141] P. De Meester, D.M. Goodgame, T.J. Jones, A.C. Skapski, Biochem. J. 139 (1974) 791-792.

[142] M.V. Capparelli, D.M.L. Goodgame, P.B. Hayman, A.C. Skapski, Inorg. Chim. Acta 125 (1986) L47-L49.

[143] R. Cini, M. Sabat, M. Sundaralingam, M.C. Burla, A. Nunzi, G. Polidori, P.F. Zanazzi, J. Biomol. Struct. Dyn. 1 (1983) 633-637.

[144] R. Cini, M.C. Burla, A. Nunzi, G.P. Polidori, P.F. Zanazzi, J. Chem. Soc., Dalton Trans. (1984) 2467-2476.

[145] R. Cini, L.G. Marzilli, Inorg. Chem. 27 (1988) 1855-1856.

[146] M. Sabat, R. Cini, T. Haromy, M. Sundaralingam, Biochemistry 24 (1985) 7827-7833.

[147] B. Knobloch, H. Sigel, A. Okruszek, R.K.O. Sigel, Org. Biomol. Chem. 4 (2006) 1085-1090.

[148] B. Knobloch, D. Suliga, A. Okruszek, R.K.O. Sigel, Chem. Eur. J. 11 (2005) 41634170.

[149] B. Knobloch, H. Sigel, A. Okruszek, R.K.O. Sigel, Chem. Eur. J. (2007) available online, DOI: 10.1002/chem.200600744.

[150] B. Song, H. Sigel, Inorg. Chem. 37 (1998) 2066-2069.

[151] H. Sigel, C.P. Da Costa, R.B. Martin, Coord. Chem. Rev. 219-221 (2001) 435-461.

[152] K.H. Scheller, F. Hofstetter, P.R. Mitchell, B. Prijs, H. Sigel, J. Am. Chem. Soc. 103 (1981) $247-260$.

[153] O. Yamauchi, A. Odani, H. Masuda, H. Sigel, Met. Ions Biol. Syst. 32 (1996) 207270.

[154] P.R. Mitchell, H. Sigel, Eur. J. Biochem. 88 (1978) 149-154.

[155] H. Sigel, Pure Appl. Chem. 70 (1998) 969-976.

[156] H. Sigel, L.E. Kapinos, Coord. Chem. Rev. 200-202 (2000) 563-594. 
[157] H. Sigel, B. Lippert, Pure Appl. Chem. 70 (1998) 845-854.

[158] A. Wong, G. Wu, J. Am. Chem. Soc. 125 (2003) 13895-13905.

[159] E. Ennifar, P. Walter, P. Dumas, Nucleic Acids Res. 31 (2003) 2671-2682.

[160] V. Tereshko, G. Minasov, M. Egli, J. Am. Chem. Soc. 121 (1999) 6970-6970.

[161] J. Liu, J.A. Subirana, J. Biol. Chem. 274 (1999) 24749-24752.

[162] H. Sigel, E.M. Bianchi, N.A. Corfú, Y. Kinjo, R. Tribolet, R.B. Martin, Chem. Eur. J. 7 (2001) 3729-3737.

[163] R. Koradi, M. Billeter, K. Wüthrich, J. Mol. Graphics 14 (1996) 29-32 \& 51-55.

[164] I. Tinoco, Jr., J.S. Kieft, Nat. Struct. Biol. 4 (1997) 509-512.

[165] J.H. Cate, A.R. Gooding, E. Podell, K. Zhou, B.L. Golden, C.E. Kundrot, T.R. Cech, J.A. Doudna, Science 273 (1996) 1678-1685.

[166] R.D. Shannon, Acta Crystallogr. A32 (1976) 751-767.

[167] W.E. Morf, W. Simon, Helv. Chim. Acta 54 (1971) 794-810.

[168] C.F. Baes, Jr., R.E. Mesmer (Eds.), The Hydrolysis of Cations, Krieger Publishing Co., Malabar, Florida, 1976.

[169] L. Helm, A.E. Merbach, Coord. Chem. Rev. 187 (1999) 151-181.

[170] S.F. Lincoln, Helv. Chim. Acta 88 (2005) 523-545.

[171] Y. Inada, A.M. Mohammed, H.H. Loeffler, S. Funahashi, Helv. Chim. Acta 88 (2005) 461-469. 


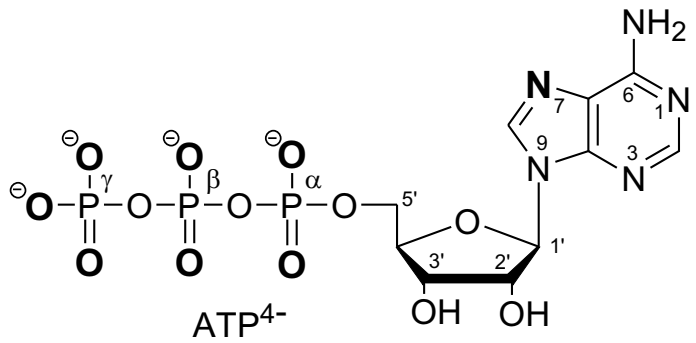

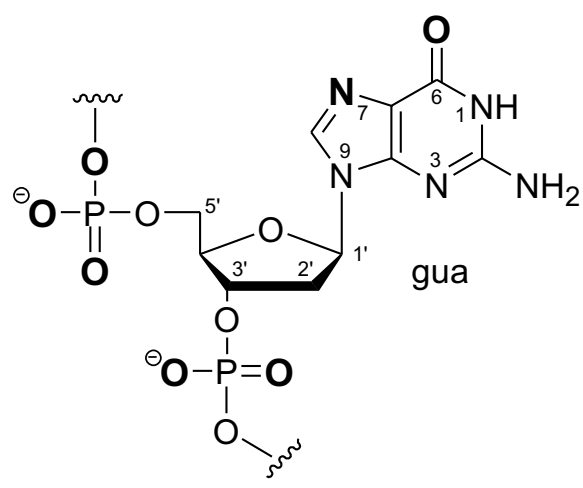<smiles>[R]n1ccc(N)nc1=O</smiles><smiles>[R]n1ccc(=O)[nH]c1=O</smiles><smiles>[R]n1cc(C)c(=O)[nH]c1=O</smiles>

cyt ura thy

Figure 1 


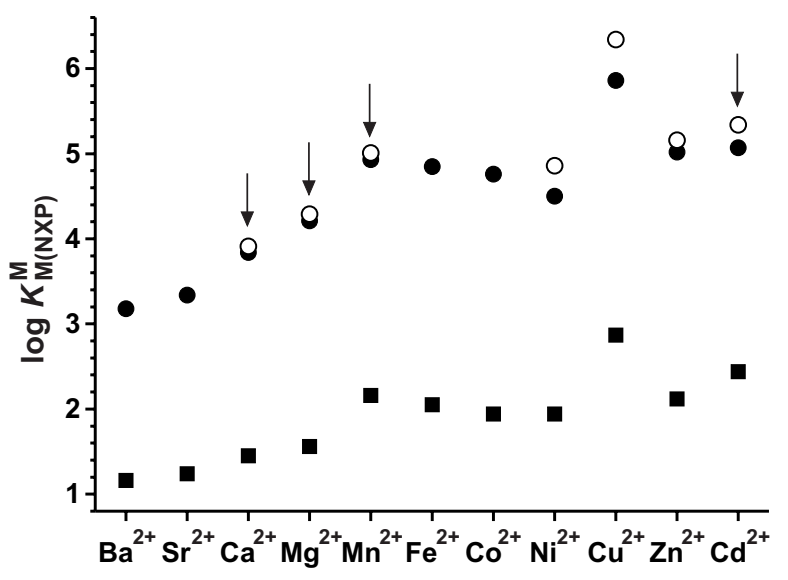

Figure 2 


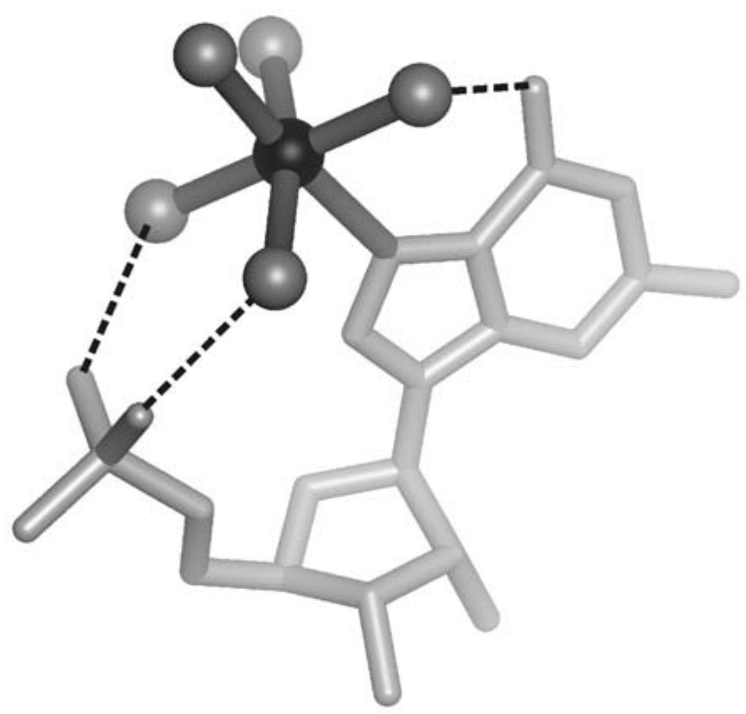

Figure 3 
A)

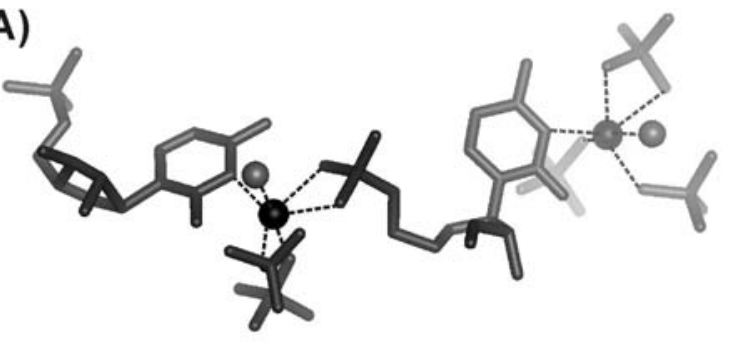

B)

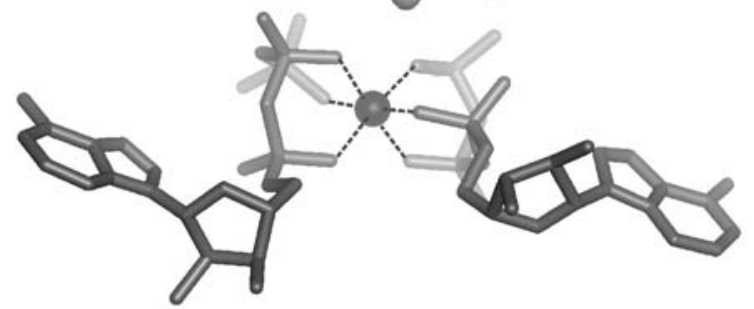

Figure 4 

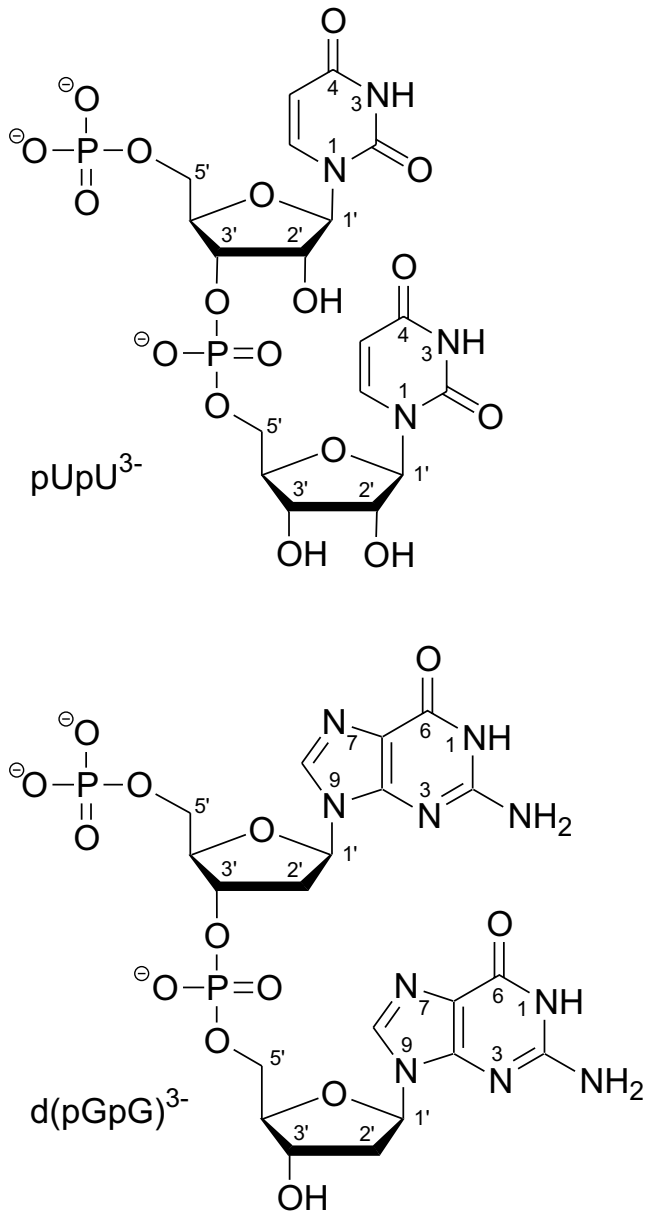

Figure 5 
A)
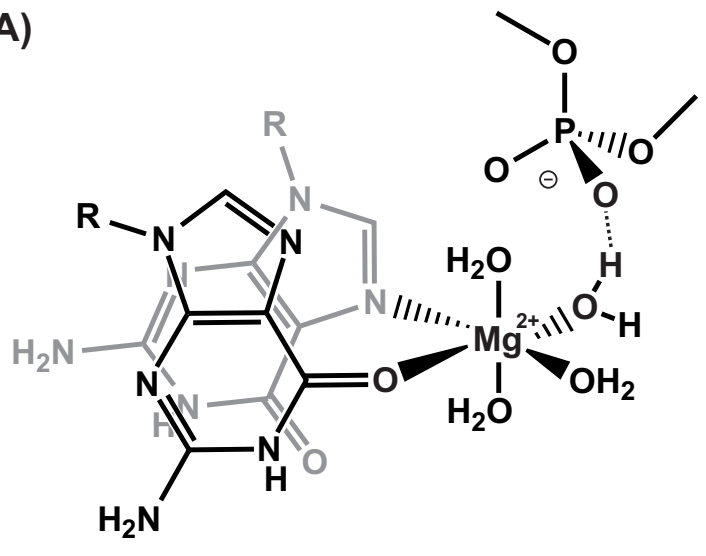

B)

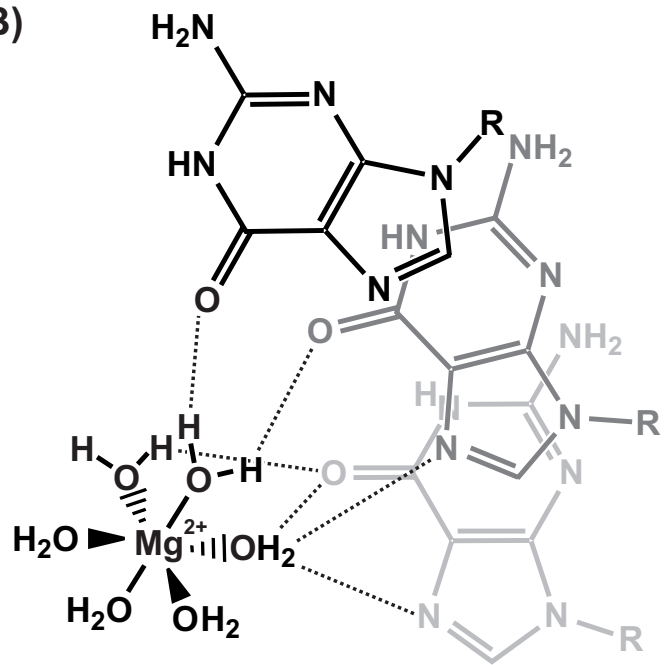

Figure 6 
A)

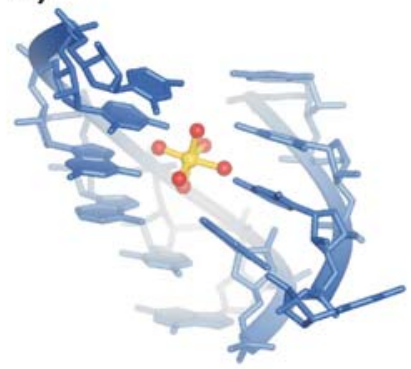

C)

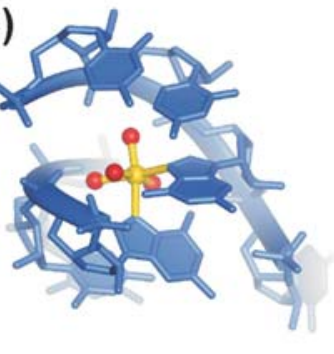

B)

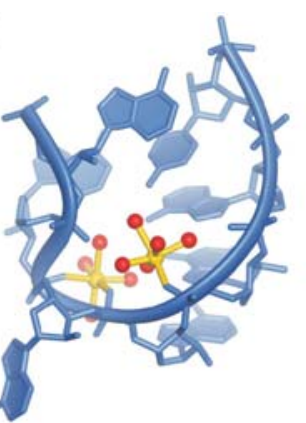

D)

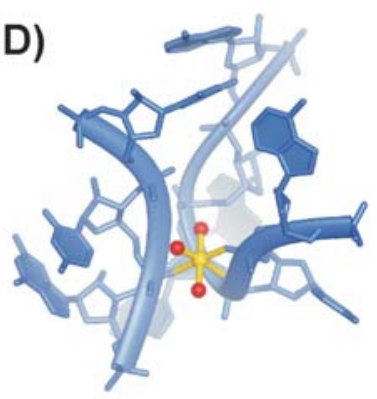

Figure 7 
A)

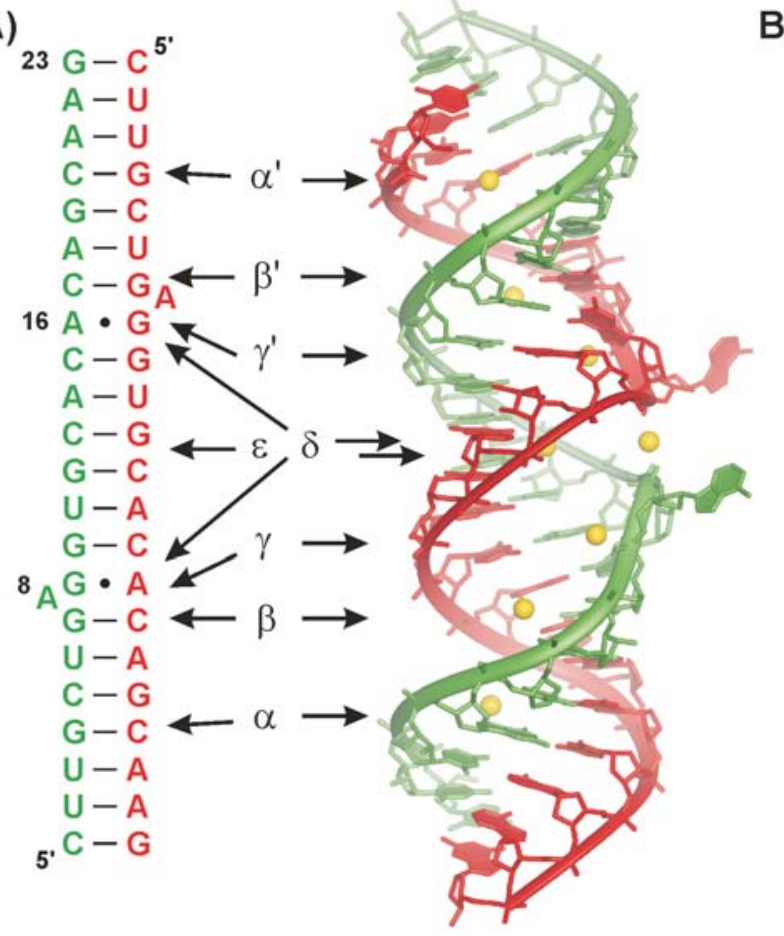

B)

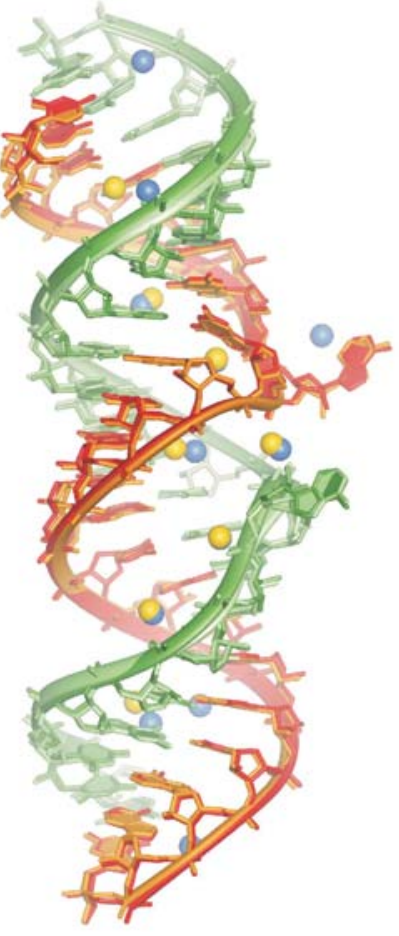

C)

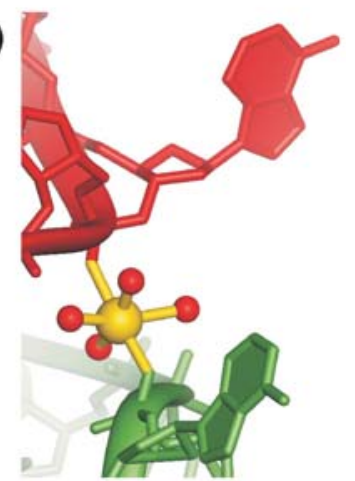

D)

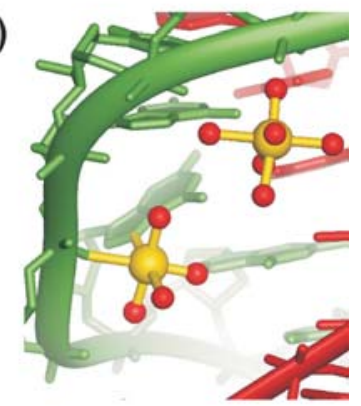

Figure 8 


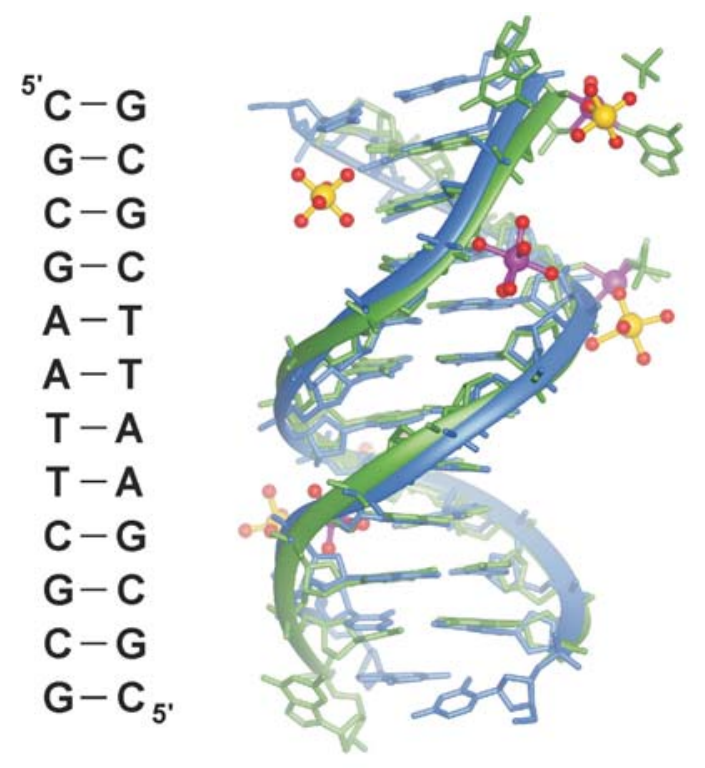

Figure 9 